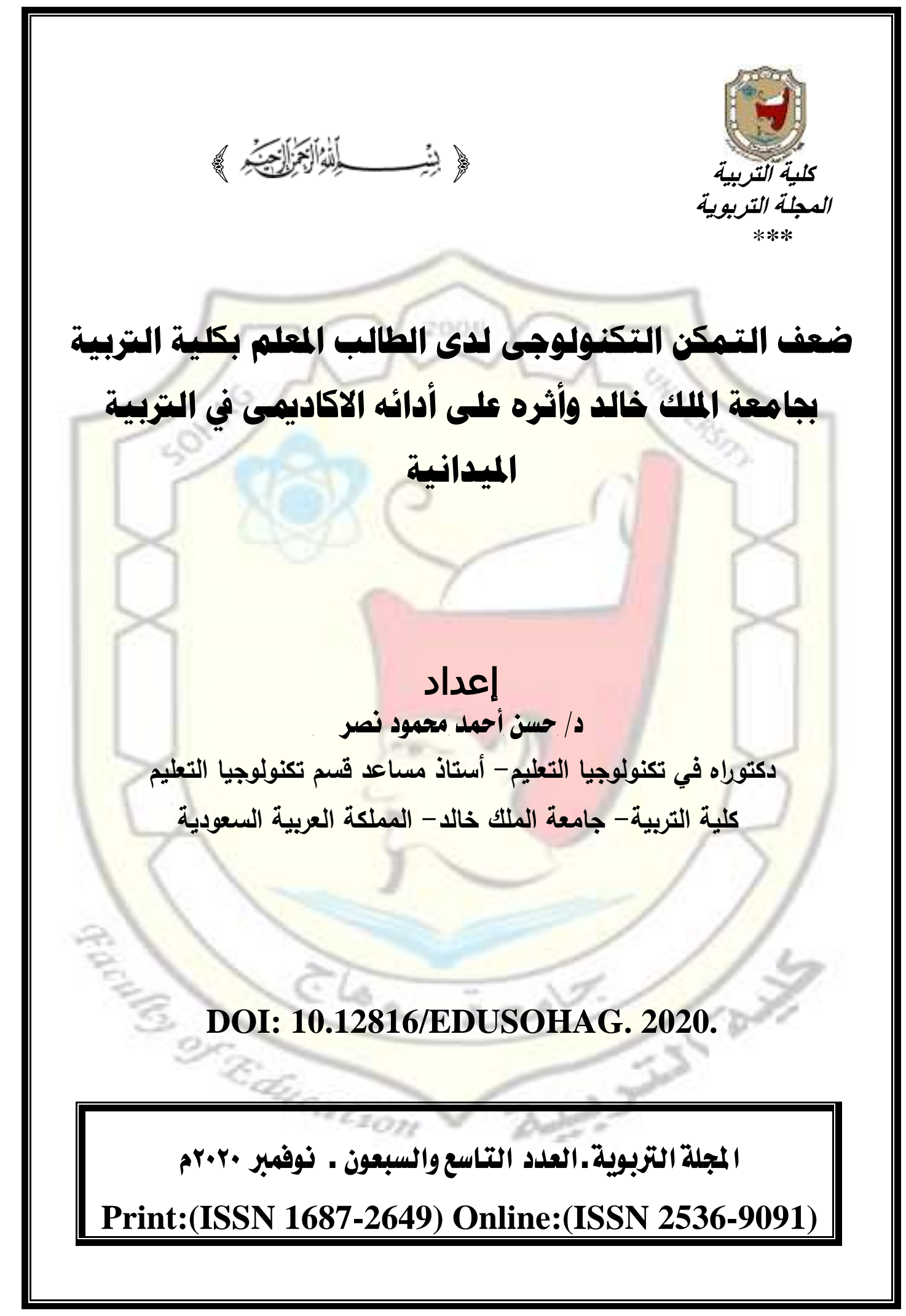


ماخمص:

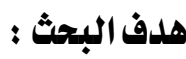

هدفت البحث إلى معرفة نقاط الضعف التكنولوجى لاى الطالب المعلم بكلية التربية -

جامعة الملك خالد، وأسباب هذا الضعف ، وتقديم مقترحات تهدف لمعالجته لاى الطلاب أثناء

مدة التربية العملية.

منهجية البحث : من

تم استخدام المنهج الوصفي التحليلي كونه الأنسب لطبيعة البحث وتحقيث أهدافه، وذلك من خلال إجراء البحث التحليلى لأهمية تقتيات التعليم والتمكن التكنولوجى لاى طلبة كلية التربية- جامعة الملك خالا ، أيضاً تم استخدام المنهج التجريبي متمثلا فى استخدام تصميم المجموعة الواحدة في إجراعتها وفقًا لطبيعة البحث.

: مينة البحث :

تكونت عينة البحث من (. (r) طالباً من طلاب البكالوريوس بالمستوى الثامن والذين يقومون بدراسة مقرر" الوسائل وتقتيات التعليم" " في الفصل الدراسي الثاني من العام - $r \cdot r|| r \cdot r \cdot|\Delta| \leq \varepsilon 1-1 \leq \varepsilon$.

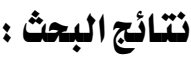

تم التأكد من صدق الأدوات وثباتها بالطرق الإحصائية المناسبة، ويعد إجراء عملية التحليل الإحصائي أظهرث التتائج وجود تلني فى مستوى التحصيل والمهام المعرفية والأدائية للطلاب حول تكنولوجيا التعليم، يث بلغت نسبة المتفوقين اب\% فقط ، والنسبة الأغلب من الطلاب كاتت متوسطة حيث بلغت 97\% . كما تبين وجود ضعف في واقع استخدام وتوظيف تقتيات التعليم وخاصة الحديثة منها، حيث كاتت نسب توظيف الطلاب لبعض برامج الحاسب الآلي في العملية التعليمية متواضعة جدا ، وفي ضوء التتائج قدم الباحث العديا من التوصيات والمقترحات لعلاج هذا الضعف فى المهام المعرفية والأدائية والتمكن التكنولوجى وتوظيف تقتيات التعليم فى التعليم بالمدارس اثناء التدريب الميدانى. المصطاحات العلمية:

تقتيات التعليم ، التمكن التكنولوجى، التربية العملية. 
ضعف التمكن النكنولوجى لدى الطالب المعلم بكلية التربية بجامعة الملك خالد...

Weak technological mastery of the student teacher at the College of Education at King Khalid University and its impact on his academic performance in field education

\author{
Dr. Hassan Ahmed Mahmoud Nasr* \\ Doctor of Education Technology, Assistant Professor, Department of Educational \\ Technology, College of Education, King Khalid University, Saudi Arabia
}

\title{
Research goal:
}

\section{Summary}

The research aimed to find out the technological weaknesses of the student teacher at the College of Education - King Khalid University, and the reasons for this weakness, and to present proposals aimed at addressing it among students during the period of practical education.

\section{Research Methodology:}

The descriptive analytical approach was used as it was the most appropriate to the nature of the research and to achieve its objectives, by conducting analytical research on the importance of educational techniques and technological empowerment among students of the College of Education King Khalid University. The experimental method was also used in the form of using one group design in its conduct according to the nature of the research. The research sample:

The research sample consisted of (30) students from eighth-level bachelor's students who study the "Teaching Means and Techniques" course in the second semester of the year 1440-1441 AH / 2020/2021 AD.

\section{Research results:}

The validity and reliability of the tools were confirmed by appropriate statistical methods, and after conducting the statistical analysis process, the results showed a decline in the level of achievement and cognitive and performance tasks for students about educational technology, where the percentage of students who excelled was only $31 \%$, and the majority of students were average, reaching 69\%. It was also found that there is a weakness in the reality of using and employing educational technologies, especially the modern ones, as the rates of student employment of some computer programs in the educational process were very modest, and in light of the results the researcher presented many recommendations and proposals to treat this weakness in the cognitive and performance tasks and technological mastery and the employment of educational techniques In education in schools during field training.

\section{Scientific terms:}

Teaching techniques, technological mastery, and practical education. 


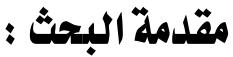

أصبح التعليم مؤشرا قوياً على تقدم الأمم، لذا يجب الاهتمام بكل أنواع التعليم في عالم تجتاحه التغيرات، وتثُفير ملامحه نتيجة الاكتشافات المستمرة، فقد أصبح من أهم سماته التدفق العلمي والتكنولوجي. والعالم المعاصر يتميز بالتغيير المستمر، والتطور السريع في مختلف جوانب الحياة، بما في ذلك المعارف والحقائق العلمية التي تتغير وتتطور بسرعة مذهلة نتيجة الانفجار المعرفي والاكتثافات الحديثة المتلاحقة والتكنولوجيا المتقدمة. ونتيجة لهذا التظور حدثت تحولات جذرية في أهداف النظم التعليمية وسياساتها متأثرة بضغوط التقدم العلمي التكنولوجي، والتربية تعتبر نظاما اجتماعيا مرتبطا بحركة المجتمع وتطوره ، يؤثر فيها ويتأثر بها، وتبعا لذلك أصبح التغيير التربوي ضرورة ويمثل ذلك تحديا أمام النظم التعليمية وتجعلها مطالبة بالتغيير المتسارع لتصبح أكثر ملاعمة للتقدم العلمي،

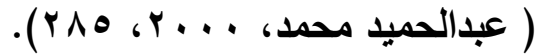
واستيعاباً للتكنولوجيا الجديدة لهذ ازداد اهتمام الباحثين في المجال التريوي، للبحث عن أساليب تعليمية جديدة تتوافق وسمات التطور في مجال التكنولوجيا وتشاعد المتعلم على استخدام التكنولوجيا في التعلم، من خلال توظيف العديد من المستحدثات التكنولوجية واستثمارها في العملية التعليمية، بحيث تساهم في مواجهة الخلل والقصور في النظم التعليمية الحالية وايجاد الحلول

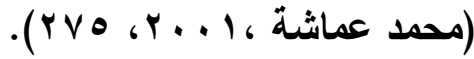
الجذرية لمشكلاتها المتعددة وأكد بلر الصالح (9919 19 1 ) أن دمج إمكانيات التكنولوجيا الحديثة من جهة، والتطبيقات التعليمية المعتمدة على أطر نظرية جليدة من جهة أخرى يمكن أن يقدم فرصة لتغيير الوجه التقليدي للتعليم من بنية جامدة تعتمد أركانها على المعلم والكتاب مصدرا وحيذا للمعرفة إلى بنية موجهة بواسطة المتعلم ومعتمدة على مصادر متعددة . ويرى عبدالله الفراء (999 (MV.199) أن قطاع التعليم من أكثر القطاعات الأساسية حاجة لتعزيز دور الحاسب الآلي والإنترنت كتقنيات حديثة تساعد فى مؤسساته المختلفة ، حيث أن هذا القطاع هو المعنى بدفع عجلة التطور إلى الأمام ، وينظر التريويون إلى أن استخدام تقتية الحاسب الآلي فى التعليم هو حل مناسب للكثير من المشكلات التعليمية التى لتى تواجهها المؤسسات المختلفة ووسيلة ناجحة لتحسين نوعية التعليم ورفع مستوياته. 
وأثشار الموسى والمبارك ( ه . . †) إلى أن تقنية المعلومات ممثلة في الحاسب الآلي، والإنترنت، وما يلحق بهما من وسائط متعددة، من أنجح الوسائل لتوفير بيئة تعليمية ثرية، والاتصال عبر الإنترنت ينمي بعض المهارات لاى المستخدم، بالإضافة إلى ما يمتاز به من قدرته على الريط بين الأشخاص، عبر مسافات هائلة وبين مصادر معلوماتية متباينة.

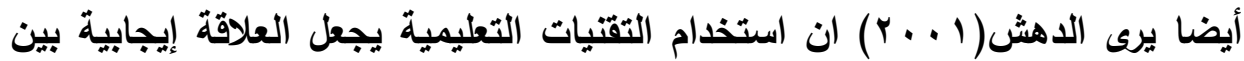
الدافعية نحو الإنجاز والتحصيل ، ويساعد على نقل المعرفة وتثبيتها خاصة فى المواد العلمية مثل (الرياضيات و الفيزياء) لانها بطبيعتها تتعامل مع الرموز والمفاهيم المجردة.

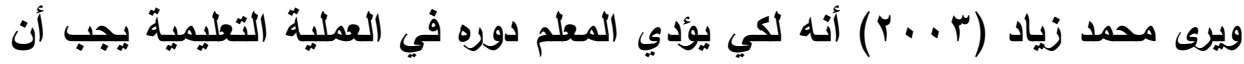
تتوافر لايه مهارات معينة، فضلاً عن امتلاكه المعلومات الكافية. ومن أهم المهارات التي لهي يمكن أن تسهم في تحقيق تعلم فعال هي مهارات تكنولوجيا التعليم، فهى من مؤشرات الكفاءة الجيدة في التدريس، وفي عمليات تطوير التدريس يجب التركيز على هذه المهارات. كما أثار حسن النعامنة (؛99 19) إلى أن التقنيات التعليمية استخدمت في برامج تدريب المعلمين بنسب متفاوتة، إذ وجد أن أسلوب المحاضرة هو الأكثر استخداماً في حين أن الحاسب الآلي والفيديو المتفاعل هما الأقل استخداماً. ويضيف أن استخدام التقتيات التعليمية في التدريب يؤدي إلى تطوير مهارات التخطيط الدراسي وإجراءات العرض والتنفيذ، واختيار الأنشطة المناسبة وإلتقويم . وتكنولوجيا التعليم عموما تكسب المعلمين المعرفة والمعلومات حول ما هو حديث في

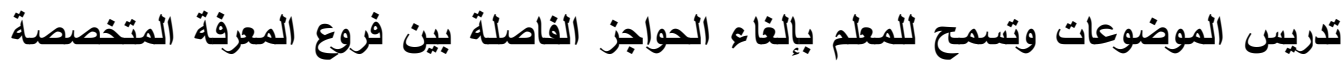
وكذلك تساعد بصورة فعالة في اكتساب المعلم مهارة توظيف معارفه عملياً، وفي إكسابه أنواع

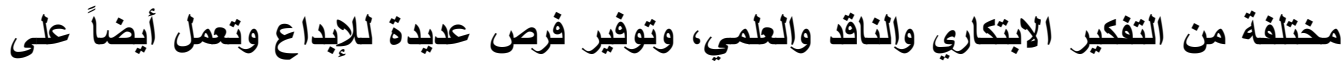
مساعدة المعلم على نشر أفكاره واستقبال أفكار جديدة أخرى قد تستفيذ منها العملية التعليمية، كما تسهم تكنولوجيا التعليم في تنمية مهارات المعلم فى التواصل بينه وبين طلبته

$$
\text { وبين معلمى المواد الأخرى (عبد العزيز الحر، r . . r). }
$$

ويلخص عبد الحافظ سلامة (19919، 19 1ه) الدور الأي تلعبه تكنولوجيا التعليم في تحسين عملية التعليم والتعلم فيما يلي: 
- إثراء التعليم : ويتم من خلال إضافة مؤثرات خاصة ويرامج متميزة. - اقتصادية التعليم : يتم من خلال تحقيق أهداف تعلم قابلة للقياس بمستوى فعال من من حيث التكلفة في الوقت والجها والمال.

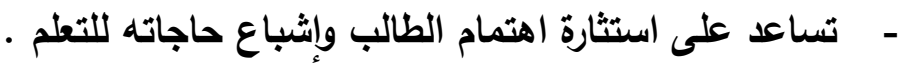
- - تساعد على زيادة خبرة الطالب مما يجعله أكثر استعداداً للتعلم . - تساعد على إثراك جميع حواس المتعلم، إذ أن ذلك يؤدي إلى ترسيخ وتعميق هذا التعلم.

- تساعد على تحاشي الوقوع في اللفظية الزائدة . - - تساعد على تكوين مفاهيم سليمة من خلال توزيع الوسائل . - تساعد في زيادة مشاركة الطالب الإيجابية وتنمي قدرته على التأمل ودقة الملاحظة وإتباع التفكير العلمي للوصول إلى حل للمشكلات . - - تساعد على تنويع أساليب التعزيز التي تؤدي إلى تثبيت الاستجابات الصحيحة. - تساعد على تنويع أساليب التعليم لمواجهة الفروق الفردية . - تؤدي إلى ترتيب واستمرار الأفكار التي يكونها الطلبة . - - تؤدي إلى تعديل السلوك وتكوين اتجاهات جديدة. وأثشار ناجي ديسقورس(9 ، . ب) إلى أن المعلم هو المسؤل عن زيادة دافعية المتعلم للتعلم ويتطلب هذا توافر معايير الجودة المهنية لديه والتي منها مهارة استخدام التكنولوجيا في إكساب المتعلمين المفاهيم والتعميمات المطلوية.

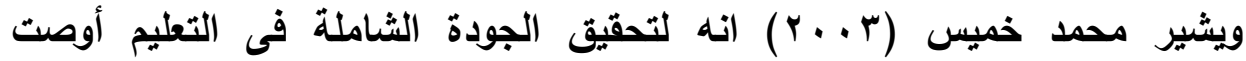
المجالس القومية المتخصصة بتوظيف تكنولوجيا التعليم ومستحدثاتها لخدمة المتعلم ، والتركيز على الاستفادة منها فى مناهج التعليم ويرامجه. والتربية الميدانية (العملية) مرحلة هامه وضرورية من مراحل إعداد الطلاب المعلمين فتعتبر اللبنة الأولي للإعداد السليم للمعلم فهي أول خطواته على طريق التدريس ويجب همبله العناية بها ، وهى تلكك الفترة الزمنية التي يُسمح فيها لطلبة وطالبات كلية التريية بالممارسة الحقيقية في الواقع لما درسوه من موضوعات مختلفة بالكلية تحت إثراف وتوجيه مربيين مؤهلين من كلية التربية والإشراف التربوى (التوجيه) أو من المؤهلين المتواجدين فى مدارس مورد 
التطبيق. فالتربية الميدانية لخريجي كليات التربية تعد تدريباً عملياً قبل الخدمة، وهى أساليب تدريب لتزويد الطلاب المعلمين بالمعرفة والمهارات التي تتطلبها مجالات عملهم وتخصصاتهم المختلفة. والخبرة الميدانية تفطي العمل الميداني، التدريب الوظيفي ، الدورات التدريبية وأشكال أخرى من التعلم تكتسب من خلال التدريب والتعلم. والتى يكون هدفها تطوير الخبرة الميدانية للطالب للمعلم وذلك لما لها من تأثير على المقررات التى يقوم بتدريسها والأخرى التى يدرسها في البرنامج التعليمى بالكلية ـ والتدريب في أثناء الخدمة وسيلة للاطلاع على كل ما هو جليد في مجال التربية والتعليم ، وضرورة لمواجهة التغيرات السائدة في أوجه النشاط الإنساني ويكون ذلك عن طريق الممارسة الفعلية والتطبيق العملي لمحتويات برامج التدريب المعدة لألك والتي تهدف إلى زيادة كفاية المعلمين وإتاحة الفرصة لهم للبحث والتجريب في المجال الحقيقي لتخصصهم مما يكون له أثر في اكتساب خبرات جديدة تساعد في القيام بواجبات العمل بالمجال بطريقة أفضل.

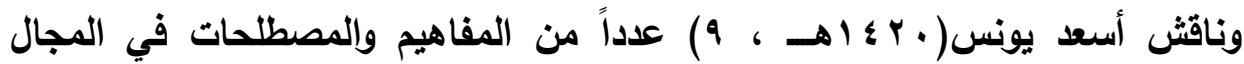
وذلك في دراسته " التكنولوجيا والتعليم واتجاهاتها المستقبلية " ، مؤكداً على أهمية تقنية التعليم في مجال الإعداد والتتريب، وأن الدول النامية هي أكثر حاجة إلى استخدام التقنيات الحديثة وإدخالها في مناهجها التعليمية.

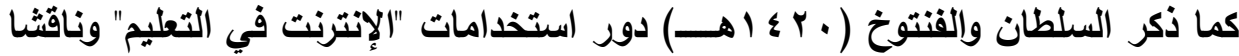
الانتقال في أساليب التعليم من التعليم التقليدي إلى التعليم باستخدام الحاسوب و"الإنترنت" وأوضحا بأن إدخال "الإنترنت" إلى قاعات البحثيمثل نقلة نوعية للمجتمع التعليمي ، وإقترحا إنشاء شبكة تعليمية أسمياها "المدرسة الإلكترونية " لتكون الخطوة الأولى للإفادة من "الإنترنت" لاحقاً، متوقعين نجاحاً كبيراً لهذه المدرسة. Molenda, Michael, Russell, James D., \& Smaldino, Sharaon ( وناقش كل من 1998) القضايا المعاصرة للتقتية في التعليم والتدريب ، حيث أكدا على تزايد الاهتمام بلمج الوسائل التعليمية المعتمدة على الحاسوب في التعليم، وتوظيف وسائل التعليم من بعد في التعليم، واستخدام التقنيات التفاعلية المتقدمة مثل الوسائط المتعددة والواقع الافتراضي، كما أكدوا على الاتجاهات الخاصة بتحديث نماذج وإجراءات تصميم النظم التعليمية بتأثير من الحركة البنيوية في التسعينيات الميلادية مما أدى إلى ازدياد الاهتمام ببيئات التعلم البنيوية 


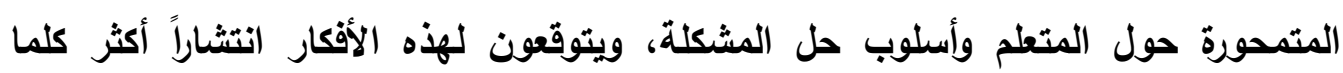
اضطلعت المدرسة بمسئولية أكبر نحو نقل مهاري حل المثلة التعلم إلى مواقع العمل.

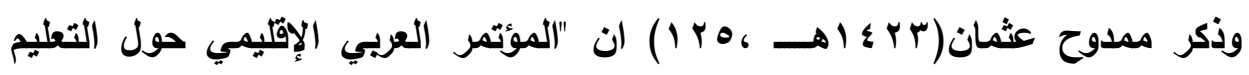

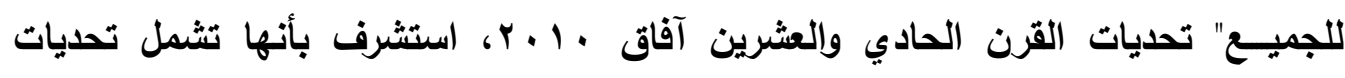

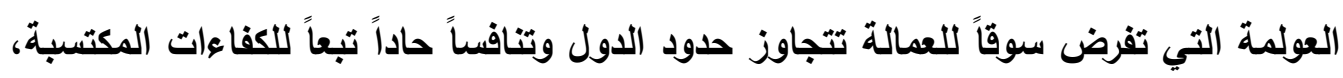

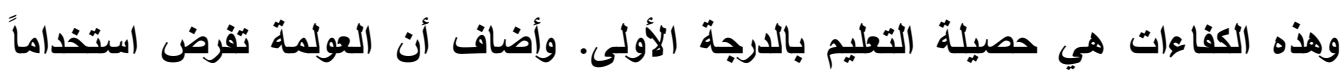

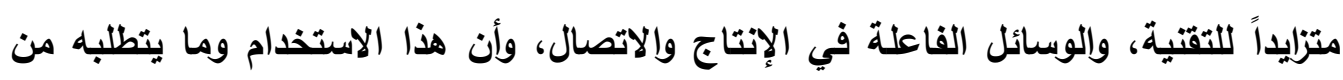

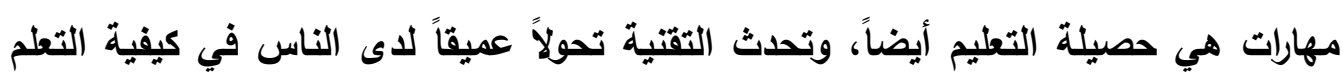

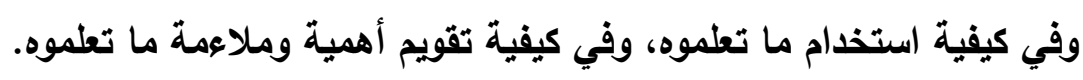

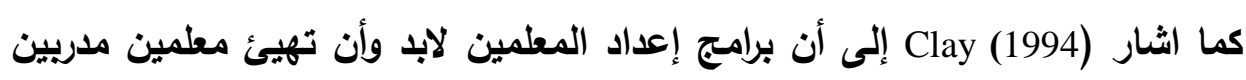

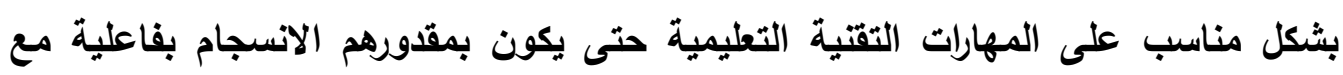

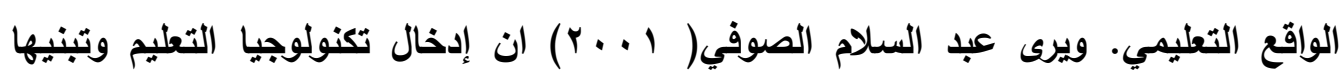

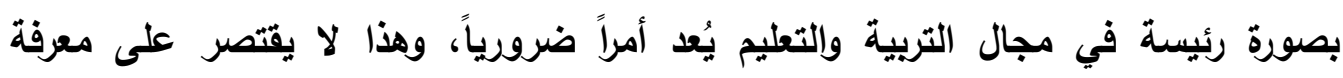

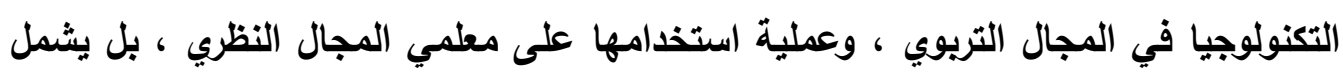

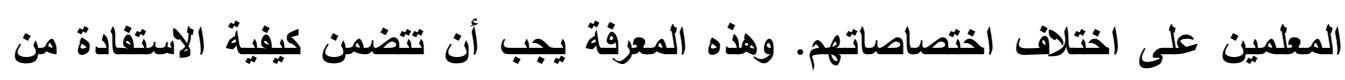

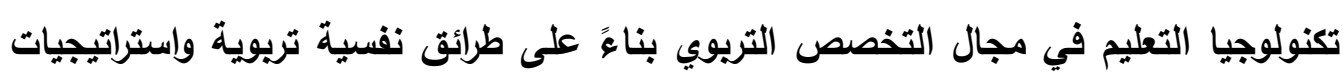

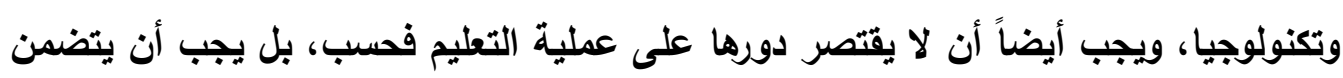

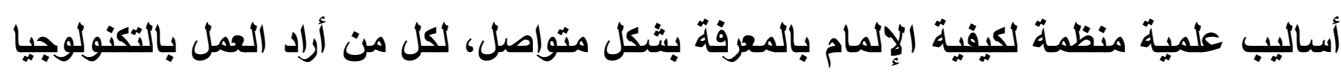
الحديثة وإدخالها في تخصصه.

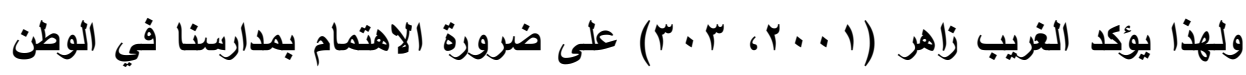

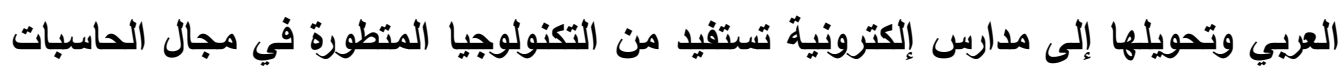

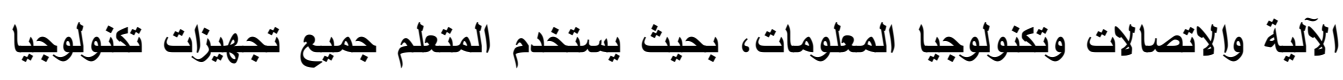

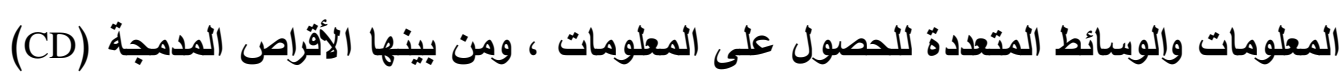

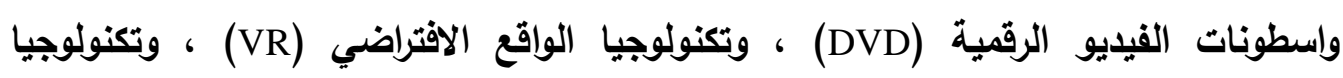

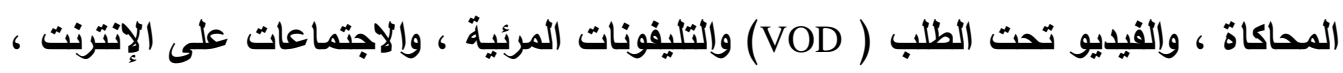

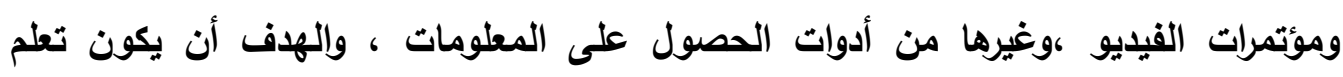


الطالب من خلال تلك المصادر المتنوعة وينفس الوقت يقيم المعلم تعلم الطالب ، ويحثه الإبداعي عن المعلومات التعليمية وطرق توظيفها.

كما يشير Ely, P (1992 إلى أن التقتيات التعليمية تعتمد بشكل كبير على مدى تطور مبادىء التعليم وتصميمه، كما أكد على أهية التقويم بتطوير مفهوم تكنولوجيا الأداء، وان ان هناك ضرورة لتبني تكنولوجيا التعليم الحديثة في التدريس، وتغيير دور المعلم في التعليم والتعلم، خاصة بعد إدخال تكنولوجيا التعليم الحديثة لغرف الصف. لما لها من القدرة على اكساب الطلاب الكفاءة الفكرية التى تتطلبها الوظائف المستقبلية التى تتطلب دقة في التعليم ودقة في حل المشكلات. وعلى هذا فإن إستخدام التقتيات الحديثة في التعليم ليس هو الهدف الأساسي بل توظيفها التوظيف الأمثل الفعال هو الهُف، إذ يؤدي ذلك إلى رفع كفاية الطالب وزيادة دافعيته وتثثويقه لتعلم المواد الدراسية المختلفة، مما يزيد من فرصة تعلمهم ويعود بالنفع الامعل على المعلم والمتعلم على حد سواء، لكن استخدام التقتيات من دون دليل واضح يثكل عبئاً إضافياً على المعلم والطالب، ويعد عاملاً من عوامل تشتيت المعلومة وضياع الهرف

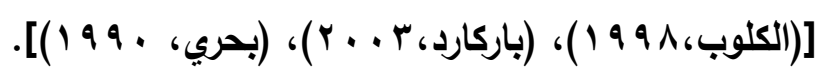

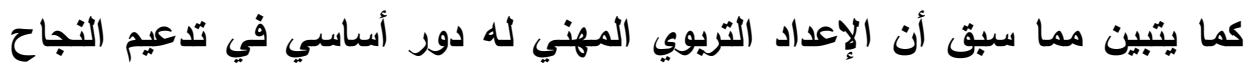

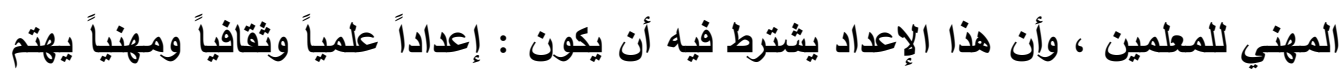
بدراسة العلوم الحديثة والمساعدة في التربية ويدرب المعلمين على استخدام التكنولوجيا

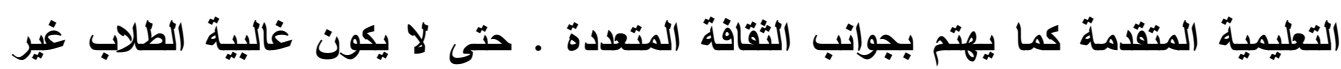
قادرين على الربط بين ما يتعلمون من معارف ومهارات وكيفية استخدامها في حياتهم العملية، وحتى لا يكون اهتماهم فقط الاعتماد على الحفظ بغرض الحصول على نتائج جيدة في الاختبارات القياسية للتخرج · لاندون

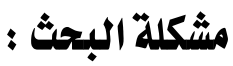
مما تقام نجد أن من سمات هذا القرن هو التقدم التقني والمعرفي بسرعة مذهلة ،

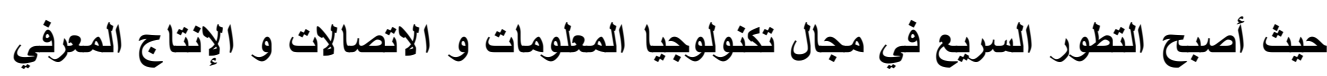
ذو تأثير على جميع جوانب الحياة ، و في ضوء هذا التطور وجد أصحاب النظريات التريوية

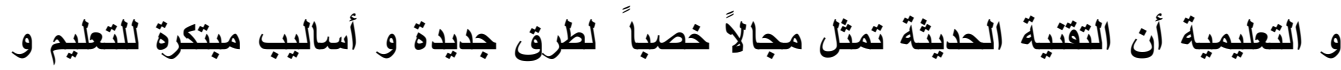


نشر المعرفة والعلم من خلال الاستفادة القصوى من هذه التقتيات و توظيفها بما يخدم رسالة التربية والتعليم ، واستخدام التكنولوجيا و بخاصة الحاسب الآلى والانترنت في تعليم وتعلم مواد التخصص أصبح أمر أساسي و عامل مؤثر في تعليم و تحسين قدرة المتعلمين على ولى ولى

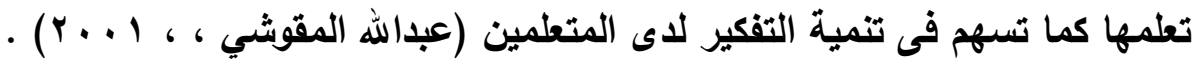
وقد وجهه المسؤولون بوزارة التربية والتعليم إلى ضرورة استخدام تقتيات التعليم و الحاسب الآلي في التدريس إلا أن معظم المعلمين يعتقدون أن استخدام التقتيات لايتناسب

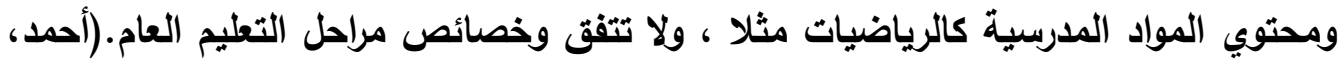

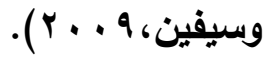
ويقع على كاهل المؤسسات التعليمية ومنها الجامعات ضرورة الاهتمام بتمية كفايات الطلاب المعلمين في عصر تكنولوجيا المعلومات والاتصال تنمية متكاملة، وتلبية احتياجاتهم الوظيفية، ومواكبة التطور في تكنولوجيا التعليم ومستحدثاتها ، وتوظيف ذلك في العملية التعليمية، بما يتناسب مع احتياجات المتعلمين وصناعة جيل المستقبل. وقد أثبتت الاراسات التي أجريت حول تلقي المدرسين التكنولوجيا الحديثة في التعليم، ان هناك نقصاً كبيراً في مجال تدريب المعلمين لاستخدام التكنولوجيا الحديثة في التدريس والتي تدعم قدرتهم على

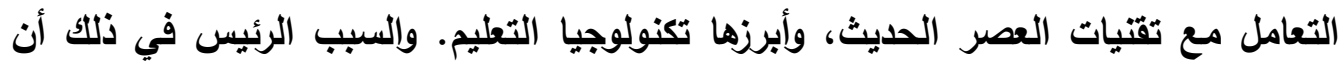
معظم الدول لا تولي اهتماماً إلى موضوع التدريب فهي تصب كل جهودها في توفير أجهزة

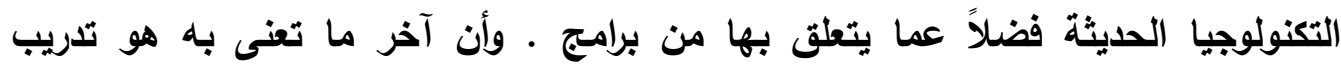

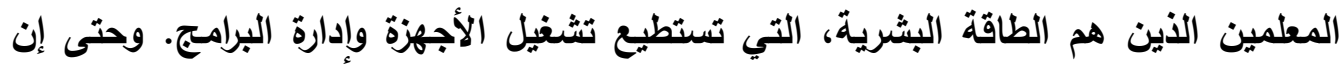
تلقى المعلمون تدريباً معيناً فإنه في الغالب يفتقر ذلك التدريب إلى الروئية المستقبلية والطرائق الفعالة التي تعود بالنفع على كل من المعلم والطالب وأن التكامل بين تكنولوجيا التعليم عبر مواد التعلم المختلفة لا يحتاج فقط إلى تغبير في أساليب التدريس بل يحتاج

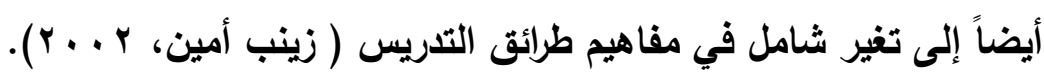
هذا وعند سؤال ومناقثة العديد من الطلاب المعلمين والذين سبث لهم دراسـة مقررات في الوسـائل التعليمية بكلية التربية ولماذا لا يتم توظيفها أثناء تدريبهم الميدانى، ظهر أن

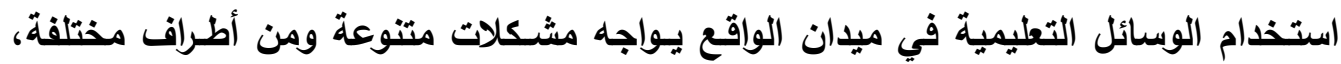
والتهمة موجهة من قبل المعلمين لبعض مديري المدارس الأين يرفضون استخدام المعلم 
للوسيلة بحجج وأعذار متعددة ، فبعض المدراء يشكك في معرفة الطالب المعلم بكيفية تثـغيل

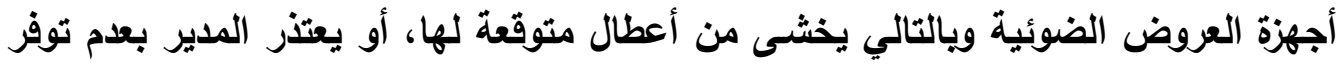
ميزانية خاصة للصيانة وشراء قطع الغيار، ويعضهم يتفاخر بإحتفاظه للاجهزة لسنوات طويلة وهي مخزنة في المستودعات ، وفي الوقت نفسه يتهم بعض مدراء المدارس بعض الطلاب المعلمين بأنهم كسالى لا يحبون العمل ويعتذرون بعدم المعرفة حتى لا يستخدموا الوسائل والأجززة التعليمية بالمدرسة ، ويعض المدراء يلاحظ على الطلاب المعلمين عدم الإلمام

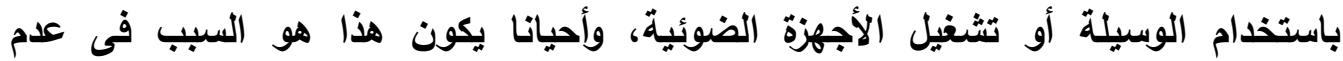

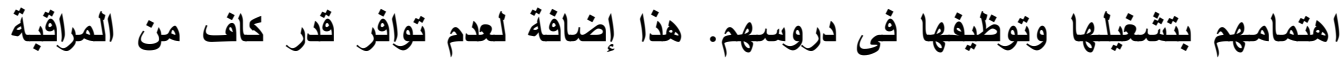
للتدريب الميدانى والذي قد يتسم بالعشوائية في كثير من الأحيان. وضعف قدرة الطلاب على فئي التطبيق الميداني للمفاهيم التى تعلموها داخل الكلية. والحقيقة أن المسئولية مشتركة بين جميع الأطراف في قضية استخام أوعدم استخدام الوسيلة التطليمية وتقتيات التطليم ، فالمطلم والمدير وريما آخرون لابد وأن يقفوا صفا واحدا لمحاولة تقليم الأفضل دائما للطلاب من التئية خلال المواد التعليمية و طريقة عرضها بواسطة الوسائل التعليمية وتقنيات التعليم الحديثة

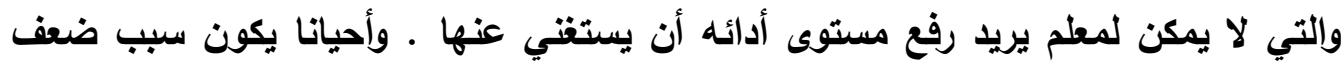
الطلاب التكنولوجى هو مقاومتهم للتكنولوجيا. ولقد تعددت الأسباب التي تعزى إليها مقاومة

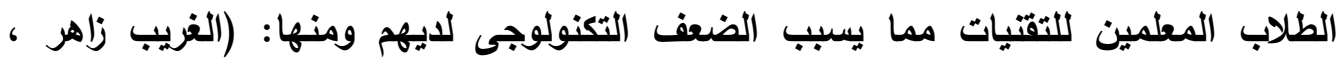
- ميل بعضهم إلى مقاومة التجديدات التريوية ، ومقاومة الاستراتيجيات والطرق والتقنيات الجديدة المغايرة لما اعتادوا عليه. - ق قلة الوعي بمفهوم تكنولوجيا التعليم والنظر إليها على أنها مجموعة من الأجهزة والآلات تستخدم في التطليم، والتي من شأنها أن تفقد التعليم ذلك الطابع الإنساني، وتجعله آليا مكانيكياً. - تخوف بعض الطلاب المعلمين من استخام الأجهزة التقية المعقدة، أو الخوف من الوقوع في الخطأ في استخدام التقنيات، الناتج عن قلة التدريب والذي يولد لادهم شعوراً

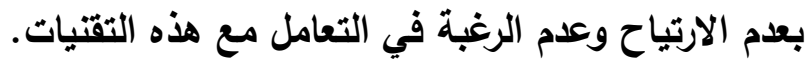
- - ندرة توافز البرامج التعليمية المناسبة للتريس ولاسيما الخاصة بالمستوى الجامعي. 
- عدم توافر الوقت الكافي للطالب المعلم وإنشغاله بالأعباء الروتينية الدراسية .

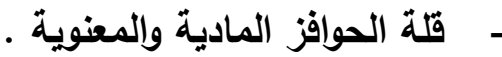
- النظر إلى التقتيات التعليمية خاصة وتكنولوجيا التعليم عامة كعامل مهرد، وتخوف بعض الطلاب المعلمين من أن تحل التقتيات التعليمية الحديثة محلهم . - التخوف من أن يفقد استخدام التقنيات التعليمية البعد النظري والفلسفي المتعمق للتدريس، مما يؤثر على نوعية التدريس وعلى كفاعته .

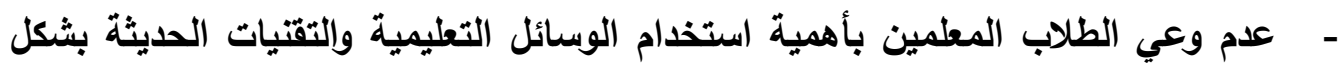
مستمر لهذا تكون النتائج غير مفيذة . - عدم توفر الدورات التريبية للطلاب المعلمين لتدريبهم على كيفية إنتاج المواد التعليمية وتطويرها مما يشكل هذا صعوية لهم عند محاولتهم توظيف التقتيات التعليمية في خدمة التعليم -

هذا ويرى الباحث انه بالرغم من تواجد فكره توظيف التقتية في خدمة التعليم في أذهان الطلاب المعلمين إلا أنها لا توظف بالدرجة الكافية في تدريس مادة التخصص. كذلك سلك بالرغم من وجود الوسائل التعليمية وتقتيات التعليم في بعض المدارس إلا أنها ليست مرتبطة بالمقررات في أغلب الأحيان ويعود ذلك إلى عدم التوافق بين تطوير المقررات الدراسية وتطوير استخدام التقتيات في خدمة التعليم ويالتالي فهى ما زالت مشكلة تعوق توظيف التقتيات في خدمة التعليم على الوجه الأمثل. وأن المشكلة ليست فى المستوى الثامن المحدد للتربية الميدانية ولكن فى المستويات التى قبلها والتى لم تقنن بطريقة تساعد الطلاب على اكتساب مهارات استخدام وتوظيف التقتيات التعليمة بشكل جيد وكافى مما يظهر الطلاب فى المستوى الثامن بهذا الثكل المتدنى ، ولهذا يكون التدريب مؤثراً وفعالاً عندما يوضع الطالب المعلم في الاتجاه المرغوب، من حيث : تعديد الأهداف وإختيار الموضوع، التعرف إلى التلاميذ، وتوظيف واستخدام التقتية مع إستراتيجية التدريس ، وكذلك التقويم. ولهذا يشير الباحث إلى ضرورة مواكبة عمليات التطوير القائمة، خاصة في مجال تكنولوجيا التعليم ومستحدثاتها ، نظراً لطبيعة مجالها المتطور، ولكون المعلم هو الأساس في هولي العملية التعليمية ، ولا بد من تلبية احتياجاته، وتطوير مهاراته ، ورفع كفاياته، وإدخاله الى مجتمع المعرفة والمعلوماتية، ليتبادل الأفكار والمعارف والمعلومات، والإطلاع على كل ما هو هوله 
جديد، في استخدام البيئات الحديثة في التعلم الاككتروني، ليتماشى مع الأدوار الجديدة للمعلم

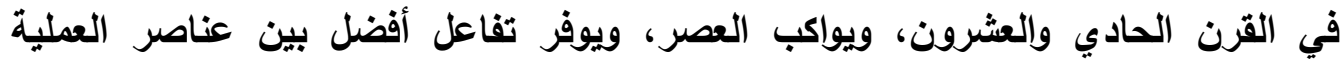
التعليمية، وتقليم منتج تعليمي جيد. ، كنلك لتلافى القصور في إلمام الطلاب المعلمين فى ولى التدريس بمستحدثات تكنولوجيا التطليم. ومما سبق ومن خلال تعامل الباحث مع الطلاب فى تدريس مقري الحاسب فى في الطئ

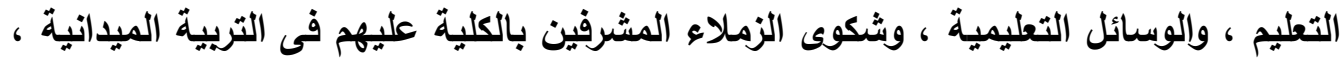

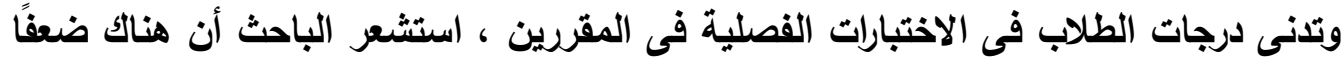
تقتيا فى توظيف الوسائل وتقتيات التعليم لايهم خاصة في تدريسهم لمواد التخصص الثاء الثاء تدريبهم الميدانى وهذا يترتب عليه ضعفاً أكاديميًا في أدائهم عند العمل بالمرحلة الإبتدائية

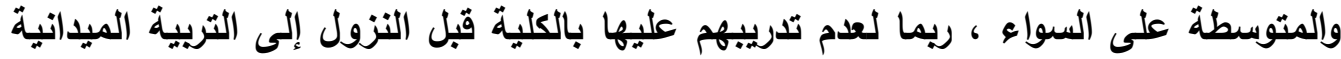
أو أثناءها. أيضًا وجدت اخطاء كثيرة فى ادائهم ومن الأخطاء التى كانت أكثر شيوعاً : ضعف قدرة الطلاب على التطبيق الميداني للمفاهيم التى تطلموها داخل الكلية. وكذلك عدام توظيف الوسائل التعليمية وتقتيات التعليم فى تدريسهم للمتعلمين ـ ومن خلال الإطلاع ايضاً

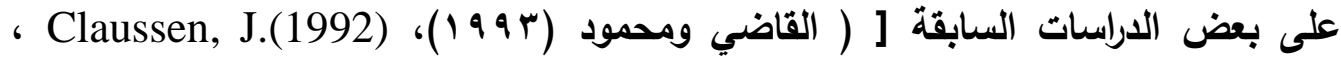

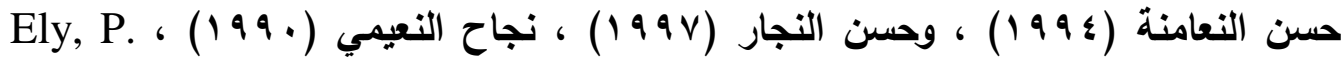

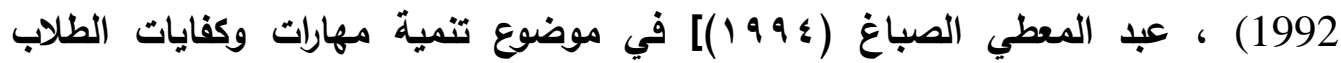
المعلمين بكليات التربية في مستحثثات تكنولوجيا التعليم والتي أكلد جميعها إلى الحاجة التهات لتدريبه ورفع كفاياتهم نحو مستحدثات تكنولوجيا التعليم وتوظيفها في العملية التطليمية، لهذا اعتبر الباحث أن مشكلة بحثه هى :

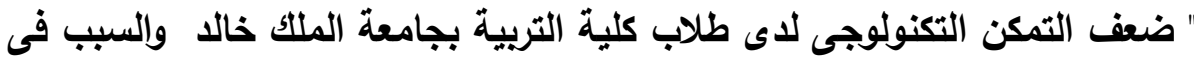
ذلك، والسبب فى عدم قدراتهم على تحمل مسئوليات القيام بعبء التريس وعدم توظيف تقنيات التعليم فى فترة تدريبهم الميدانى". 


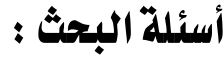

1. ما اسباب الضعف التكنولوجى لاى الطالب المعلم بكلية التربية بجامعة الملك خالد؟. r. ما أثر ضعف التمكن التكنولوجى لاى الطالب المعلم بكلية التربية بجامعة الملك خالد التهابل على أدائه الأكاديمى في التربية العطلية؟. r. ما الحلول المقترحة لمعالجة هذا الضغف التكنولوجى لدى الطالب المعلم بكلية التربية بجامعة الملك خالد أثناء التربية الميدانية؟.

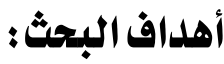

1. الكثف عن نقاط الضعف التكنولوجى لاى الطالب المعلم بكلية التربية - جامعة الملك خالد أثناء فترة التربية العملية. r. الكثف عن أسباب هذا الضعف التكنولوجى لاى الطالب المعلم بكلية التربية -جامعة الملتك خالد أثناء فترة التربية العملية. r. تقيم مقترحات تهاف لمعالجة هذا الضعف التكنولوجى لاى الطالب المعلم بكلية التربية جامعة الملك خالد أثناء فترة التربية العملية. ؛. توجيه الطالب المعلم بكلية التربية جامعة الملك خالد لزيادة تمكنه التكنولوجى في تدريسه لمادة التخصص بالمدرسة كجزء أساسي قيل التزول إلي التربية العملية. ه. توجيه المشرفين على الطلاب المعلمين بكلية التربية جامعة الملك خالد أثناء فترة التدريب الميدانى للاهتمام بالجوانب التقتية والأكاديمية ومشكلات تدريسها إلى جانب

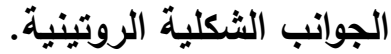

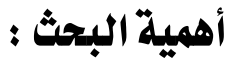
1. قد تُسهم نتائج هذا البحث في تطوير أداء الطلاب المعلمين بكلية التربية جامعة الملك

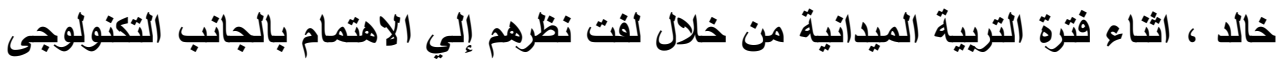
بالتوازي وينفس درجة الاهتمام بالمحتوى الأكاديمي. r. قـ تُسهر نتائج هذا البحث في إعادة النظر في برامج الإعداد داخل كلية التربية بجامعة

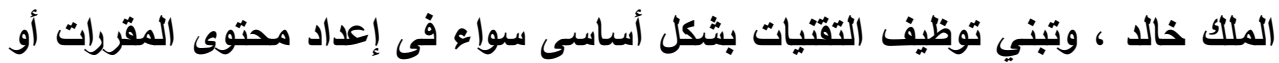
الأنثطة وكنلك طرق التدريس للمقررات المدرسية ضمن إعداد المطلم بكلية التربية. 


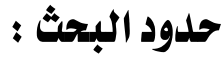

ا. الحدود البشرية: عينة قصدية من طلاب البكالوريوس بالمستوى الثامن فى كلية التربية بجامعة الملك خالد والذين يدرسون مقرر" الوسائل وتقتيات التعليم" . r. الددود المكانية: كلية التربية بجامعة الملك خالا بمدينة أبها.

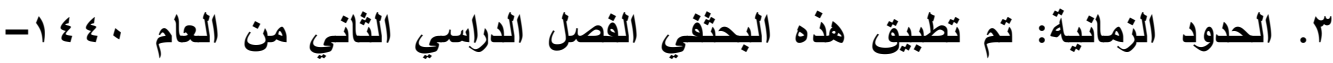

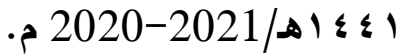

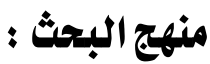

تم استخدام المنهج الوصفي التحليلي كونه الأنسب لطبيعة هذه البحثوتحقيق أهدافها، وذلك من خلال إجراء البحثالتحليلية لأهمية تقتيات التعليم والتمكن التكنولوجى لدى الدي طلبة كلية التربية بأبها. أيضاً تم استخدام المنهج التجريبي للإجابة عن اسئلة البحث.

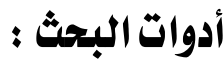
تم استخام أداتين (اختبار تحصيلي فى المعلومات التكنولوجية - مقياس عن نواحى الضعف التكنولوجى وأسبابه لاى الطلاب) . مصطلحات البحث : ت البح

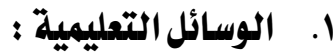
يرى يسن قتديل (1999) أن مصطلح الوسائل التعليمية يكفي للالالة على كل من الوسائل التي يستخدمها المطلم في التدريس، وتلكت التي يستخمها المتعلم في تعلمه لأنها

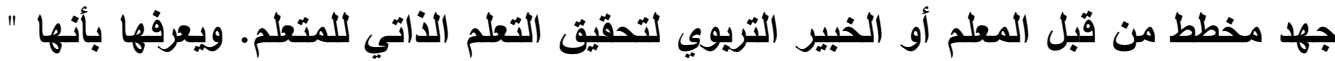
كل ما يقدم أو يسهم في تقديم مادة تعليمية ضرورية لعملية التعلم كما تصفها وتحددها الأهداف التعليمية، وتستخدم كجزي أساسي متفاعل مع بقية إجراءات منظومة التدريس لتحقيق الأهداف التعليمية " . . ل وتعرف إجرائياً بانها أثثياء مادية محسوسة ومنظورة يوظفها الطالب المعلم بكلية

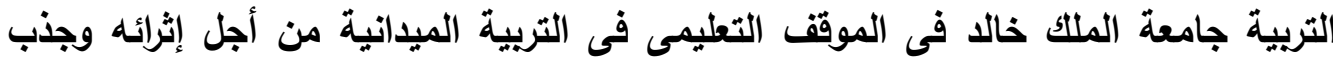

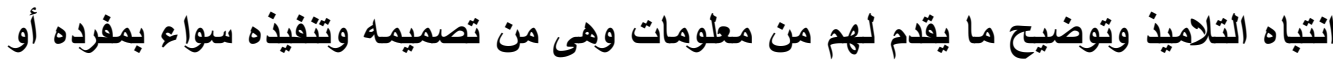


فى وجود التلاميذ ويمساعدتهم ، وهى جزء أصيل فى خطة الدرس وجزء أساسى من المجال الإدراكي للتمليذ فى الموقف التعليمى .

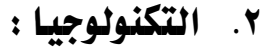

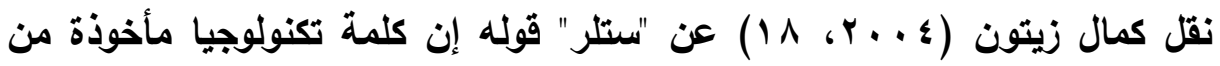

الأصل اللاتيني (Textere) وتغني ينشئ أو ينسج وتثير إلى تطبيق المعرفة العلمية. وقد انتقلت إلى اللفة الفرنسية في صورة معدلة هي (Technique) ثم انتقلت إلى اللفة الانجليزية (Technology) والتي ترجمت إلى العربية تكنولوجيا. ومن المغنى اللغوي لكلمة تكنولوجيا يتضح أنها ترتبط ارتباطاً وثيقاً بالعلم التطبيقي التقني، والدليل على ذلك يتضح في أصل الكلمة باللغة الانجليزية Technology الذي بغني تقتية أو (تقانة) أي أن تقنية وتكنولوجيا بنفس المعنى (حسن شحاته و زينب النجار ، .) (101، r...

ويقصد بالتكنولوجيا إجرائياً في هذا البحث " بأنها منظومة متكاملة من الأجهزة والبرمجيات ، والإجراءات والعمليات ، التي تؤدي إلى تحقيق الأهداف المنشودة بفاعلية التهاية وكفاءة لاى الطالب المعلم بكلية التربية بجامعة الملك خالد أثناء أداءه فى التربية الميدانية .

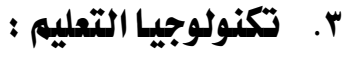
يعرفها سيلز و ريتثي ( 11؛ اهـ ،94) بأنها" النظرية والتطبيق في تصميم المصادر والعمليات وتطويرها واستخذامها وإدارتها وتقويمها من أجل التعلــ".

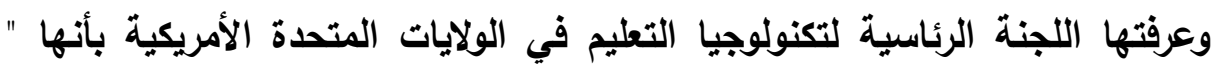

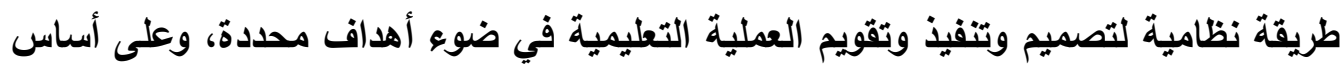

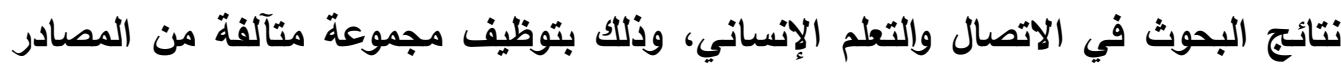

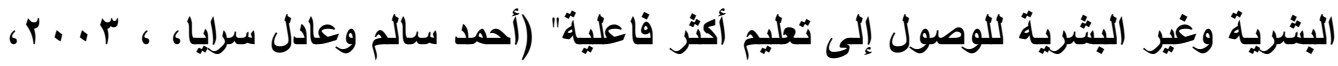
.$(r V$ وتعرف إجرائيا بأنها : الوسائل التقنية التى يصممها ويستخدها الطالب المعلم بكلية التربية في تعليم مادة التخصص خصوصاً التقتيات التفاعلية المعتمدة على الحاسوب

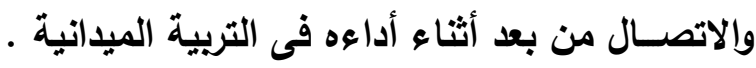


ع. التمكن التكنولوجى:

التدريب من أهم أساليب الإنماء المهني وهو عبارة عن جهود منظمة ومخططة لتطوير معارف ، وخبرات، واتجاهات الطلاب، وطرائق أداء سلوكهم بغية تمكينهم من استغلال إمكاناتهم وطاقاتهم بما يساعد على رفع كفايتهم في ممارسة أعمالهم التدريسية بطريقة منتظمة. كما تهتم التنمية المهنية بتحسين الأداء المهني للمعلم في ضوء برئم بـامج منظم ومخطط ، يمكنه من إتقان الكفايات المطلوية للمهنة والارتقاء بطاقاته الإنتاجية بما يرفع من مستوى التعليم والتعلم.وتوظيف تقتيات التعليم هو استخدام إمكانيات التقنية الحديثة لخدمة

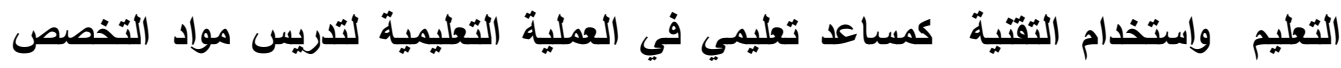
المختلفة سواء كاتت نظرية أو عملية بما يحقق أهداف هذه المواد بالتعليم العام. ومن هنا يعرف التمكن التكنولوجى إجرائيا : هو أن يوظف الطالب المعلم بكلية

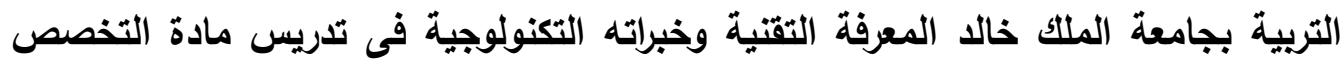
بكفاءة عالية أثناء أداءة فى التربية الميدانية .

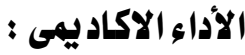

يعبر أداء المعلم عما يقوم من أنثطة وعمليات وإجراءات وسلوكيات تعليمية تتعلق بعملية التدريس وطريقة التقويم. وهو درجة قيام المعلم بتنفيذ المهام التعليمية الموكلة إليه وما يبذله من ممارسات وأنشطة وسلوكيات تتعلق بمهامه المختلفة تعبيرًا سلوكيًا.

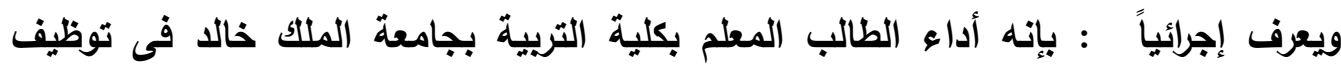
المعرفة الأكاديمية والتقنية وخبراته التخصصية فى تدريس مادة التخصص بكفاءة بله عالية أثناء أداءة فى التربية الميدانية . 0. التربية الميليدانية : تعرفها أحلام مبروك ( ( . ب) بإنها نشاط تربوي ينفذ وفق خطة منظمة، خلال فترة زمنية محددة يمارس الطالب المعلم خلالها عملية التدريس، ويطبق الجواتب النظرية (التريوية والنفسية والثخصية) التي درسها من قبل كمتطلب سابث، ويتحمل مسؤولية قيادة المتعلمين تحت إثراف فني دقيق، كما يتحمل مسؤولية المشاركة في الأنشطة غير الصفية داخل البيئة المدرسية . 
وتعرف إجرائياً : بإنها كل الطرق الوسائل والأنشطة والاستراتيجيات التي يتخذها المشرف والمعلم المتعاون بالمدرسة بقصد إكساب الطالب المعلم بكلية التربية بجامعة الملك خالد ، الجواتب المعرفية والمهارية والانفعالية الخاصة بعملية التدريس لمادة التخصص التى بالى لتصنية

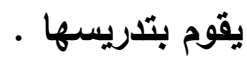

\section{الدراسات السابقة للبحث:}

قامت نجاح النعيمي (·99 ( 9 ) بدراسة هدفت إلى التعرف على أثر استخدام برنامج لتنمية الكفايات اللازمة للطلاب المعلمين في مجال تقنيات التعليم، وكذلك أثر أسلوب التعلم على تحصيل عينة من طلاب جامعة قطر وأدائهم للمهارات المطلوية نحو التعلم الذاتي. و تكونت عينة البحثمن (ع • 1) طالبة من طالبات السنة الثالثة قسمت إلى مجموعتين تجريبيتين بحيث تحتوي كل مجموعة على طالبات مستقلات وطالبات معتمات، وطبق البرنامج على المجموعة التجريبية، أما طلاب المجموعة الضابطة فدرسوا نفس المستوى بالطريقة العادية. وقد توصلت البحثالى عدة نتائج من أهمها: أن اختلاف طريقة التدريس المتبعة ( برنامج قائم على الكفايات) كان له أثر دال على التحصيل المعرفي فقط فى حين لم تظهر فروق دالة على الأداء العملي أو الاتجاهات نحو التعلم الذاتي . وأجرى (1992).Claussen, Jراسة هدفت إلى التعرف على مدى إدراك معلمي التقتيات التعليمية في الولايات المتحدة الأمريكية للكفايات الوظيفية الضرورية لهم للنجاح داخل غرفة الصف، وأظهرت النتائج اتفاق العينة مع (Y r) مبأ من مبادى الته التقيات التعليمية، وتوافقت الكفايات المقترحة مع العمر، والمستوى التعليمي، حيث أثثارت المجموعات ذات الأعمار الكبيرة والمستويات التعليمية العالية بلرجة كبيرة إلى أهمية الكفايات الوظيفية الضرورية للنجاح داخل غرفة الصف. كما قام Ely,P(1992 بتحليل محتوى بعض الاراسات في مجال تقتيات التعليم، ناقش خلالها عشرة اتجاهات في مجال التقتيات التعليمية، وخلصت البحثإلى أن التقتيات التعليمية تعتمد بشكل كبير على مدى تطور مبادى التعليم وتصميمه، كما أكدت البحثعلى أهمية التقويم بتطوير مفهوم تكنولوجيا الأداء، وأن هناك ضرورة لتبني تكنولوجيا التعليم الحديثة في التدريس، وتغيير دور المعلم في التعليم والتعلم، خاصة بعد إدخال تكنولوجيا التعليم الحديثة لغرف الصف. 


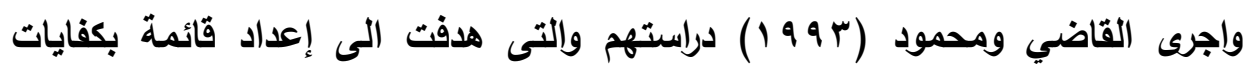

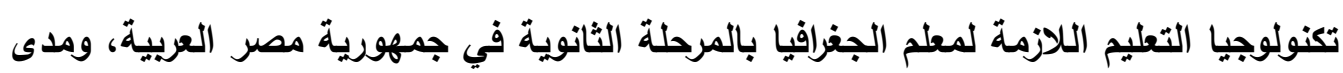

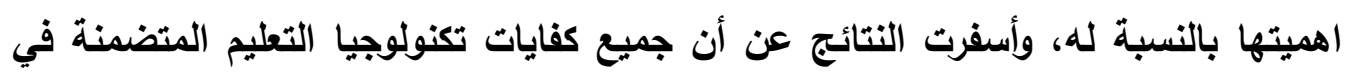

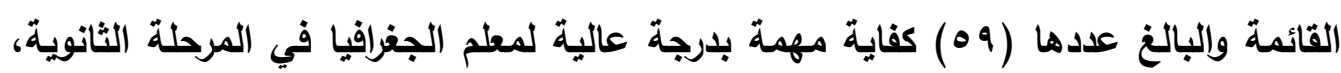

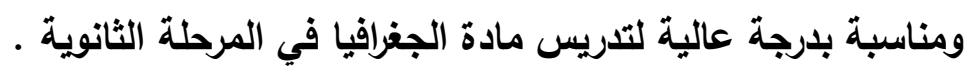
كذلك قدم (Yalin, H(1993) دراسة هدفت إلى تحديد أهم الكفايات التقتية التعليمية

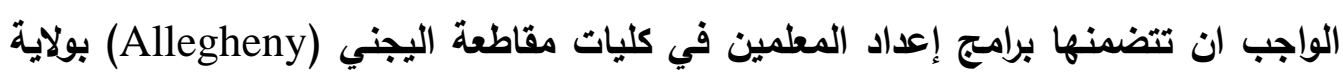

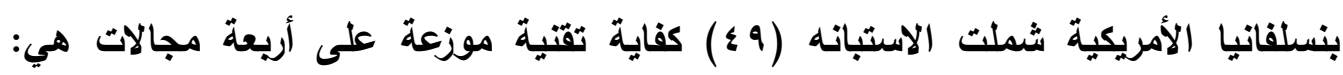

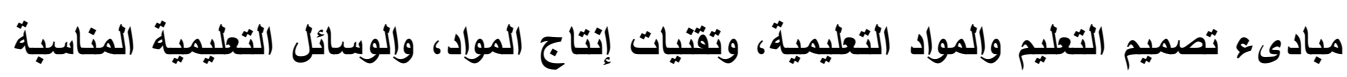

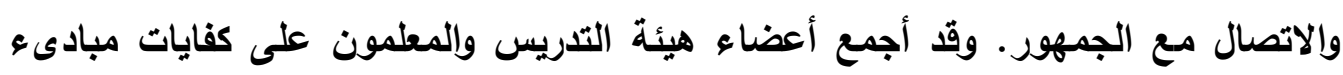

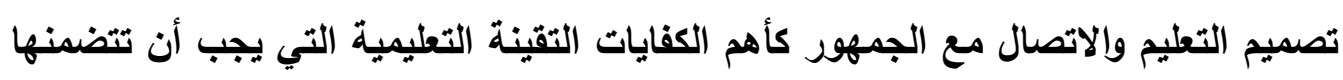

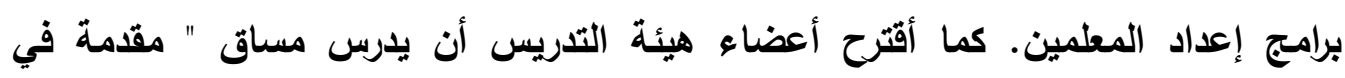

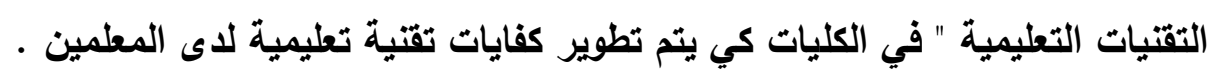

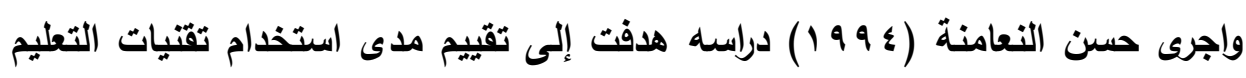

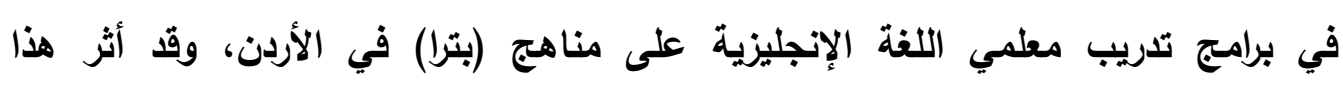

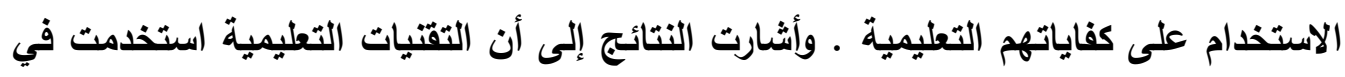

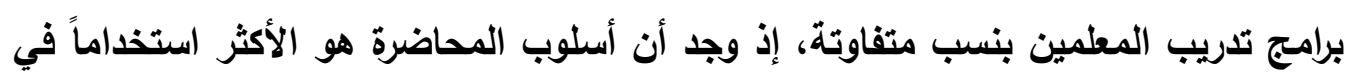

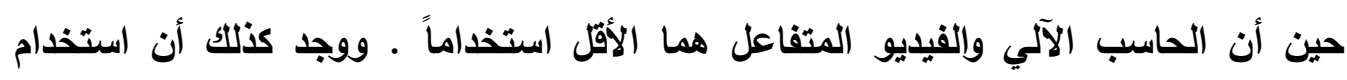

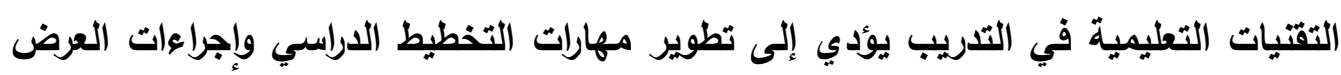

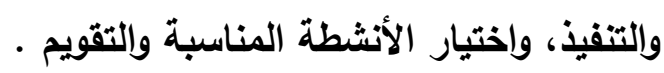

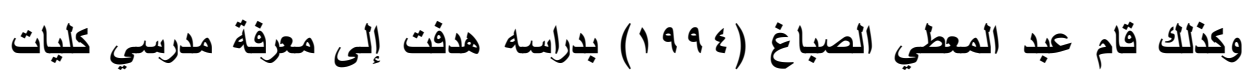

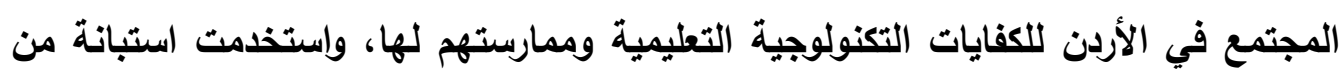

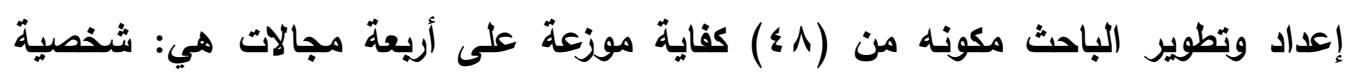

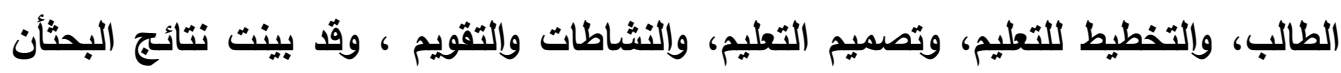

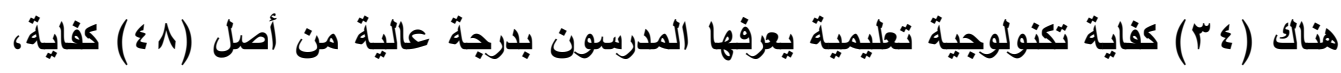

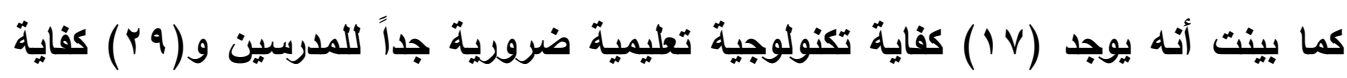


متوسطة الضرورة. كما أظهرت البحثأن المدرسين في كليات المجتمع يمارسون (9) كفايات تكنولوجية بلرجة عالية، و(0) كفاية يمارسونها دون مستوى الإتقان أي بلرجة متوسطة.

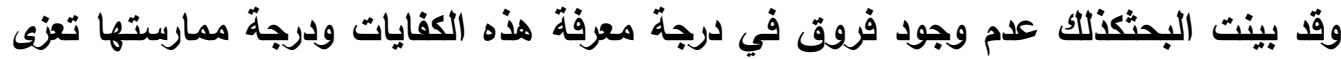
للجنس أو السلطة المشرفة وبينت وجود ارتباط موجب دال إحصائياً عند أفراد العينة بين

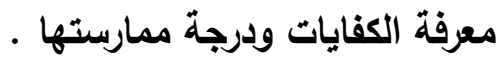
كما أجرى (1994).Clay,M دراسة عن الكفايات التقنية التعليمية لاى المعلمين المبتدئين لتعليم المرحلة الثانوية بهذف التأكد أذا كانت برامج إعداد المعلمين تهيئ معلمين مدربين بشكل مناسب على المهارات التقتية التعليمية حتى يكون بمقدورهم الانسجام بفاعلية مع الواقع التعليمي. وقد أظهرت النتائج أن لاى المعلمين كفايات أقل في تقنيات التعليم من توقعات أعضاء هيئة التدريس في الجامعة في حين تدنت توقعات أعضاء هيئة التدريس عن المقاييس الدولية . واخيراً دراسة حسن النجار (99v 1 (1التى هدفت إلى معرفة مدى توافر الكفايات التقتية التعليمية لاى معلمي مرحلة التعليم الأساسي في الأردن وممارستهم لها من وجهة

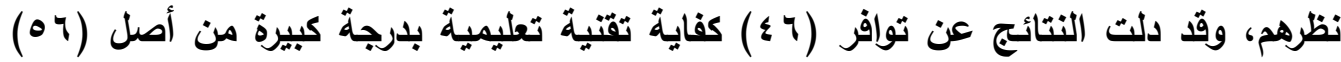

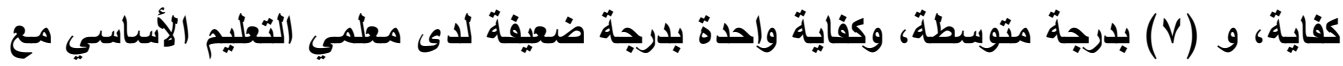
وجود ارتباط موجب دال إحصائياً بين توافر الكفايات التقتية التعليمية وممارستها عند أفراد

\section{ومن خلال استعراض الدراسات السابقة تبين ما يلي :}

اهتمت بعض الدراسات بتحديد الكفايات الضرورية لإعداد المعلمين في مجال تكنولوجيا التعليم كما في دراسة القاضي ومحمود (ب9 9 ( ) ، ودراسة 1992).Claussen, J. في حين تناولت بعض الاراسات الكفايات الخاصة بتكنولوجيا التعليم التي ينبغي ان يكتسبها الطلاب المعلمون أثناء إعدادهم في الكليات والجامعات مثل دراسة حسن النعامنة ( 99 ( ) ) ، حسن النجار (99v ( ) ). ويبيت البعض منها ان استخدام أسلوب التعليم القائم على الكفاية يزيد من كفاءة المدرس التدريسية مما ينعكس ايجابياً على تحصيل طلبته، مثل دراسة نجاح النعيمي (.99 19). كما ظهر التقدير لأهمية التقتيات التعليمية ودورها في إعداد استراتيجيات التدريس وتطويرها مثل : دراسة Ely,P(1992 ويعضها أثشار لوجود إرتباط موجب بين توافر 


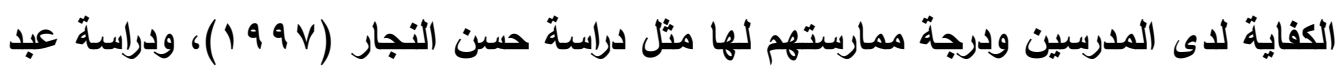

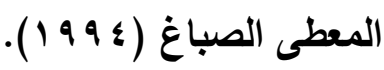
كما لاحظ الباحث انه لم توجد بينها دراسة اهتمت بالتمكن التكنولوجى لاى الطالب المعلم وأثر ذلك فى أدائه الاكاديمى فى التربية الميدانية وهو موضع البحث الحالى .

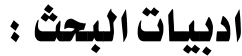
اولاً : الوسائل التعليمية Instructional media

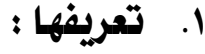

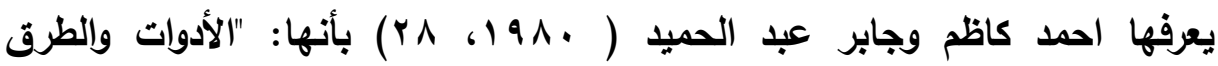
المختلفة التي تستخدم في المواقف التطليمية والتي لا تعتمد كلية على فهم الكلمات والرمهوز

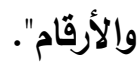

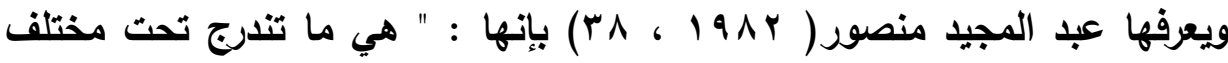
الوسائط التي يستخمها المعلم في الموقف التطليمي، بغرض إيصال المعارف والحقائق

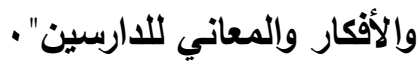
كما تعرف بأنها أثياء مادية محسوسة ومنظورة توظف فى الموقف التعليمى من أجل إثرائه وجذب انتباه الطلاب وتوضيح ما يقدم لهم من مطومات التياء ومن تصميم وتنفيذ المعلم سواء بمفرده أو فى وجود الطلاب ويمساعدته ، وهى جزء أصيل فى خطة الدرس وجزء

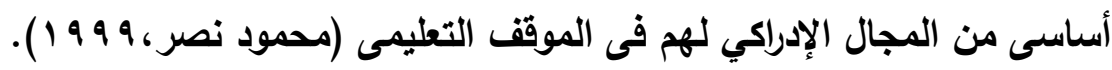
ويصفة عامة يمكن القول أن الوسيلة هى كل ما يستخدم لتحقيق غاية، وعليه فإن الن الوسائل ليست غايات فى حد ذاتها، ولكنها تستخدم لتحقيق غايات، وتختلف الوسائل فى التى

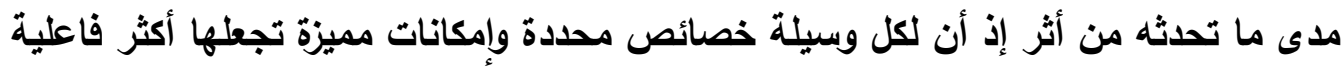
من غيرها فى تحقيق غايات معينة، وتتعدد الوسائل بتعدد الغايات، كما قد تستخدم أكثر من وسيلة لتحقيق غاية واحدة. وقد تدرّج المربون في تسمية الوسائل التعليمية فكان لها أسماء

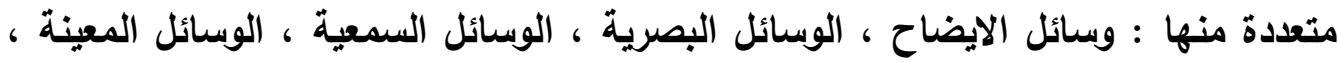

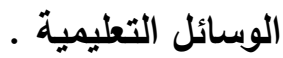
ولهذا يمكن أن تعرف فى ضوء المعنى السابق بأنها : هى كل ما يستخدم لتحقيق الغاية الكبرى من وراء عملية التعليم ألاوهى التعلم فلا تعلم بدون وسيلة. 
r. خصائصها:

الصياغة السابقة لا تعكس بدقة طبيعة الوسائل التعليمية، ومن هنا تظهر أهمية تحديد الخصائص التى تحدد طبيعتها حتى تتضح مكوناتها وأبعادها. وفيما يلى بعض الملامح

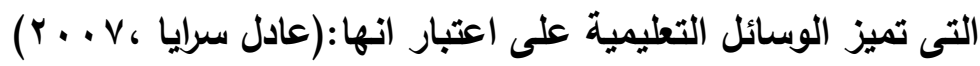
ا ـ. أدوات ترميز الرسالة التعليمية .

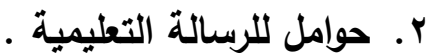

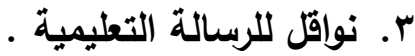
وفيما يلى توضيح لألك : 1. الوسائل أدوات ترميز الرسالة:

الوسيلة هى الرساية ويشير هذا المعنى إلى أن الوسيلة تشكل الرساية وأنه يصعب

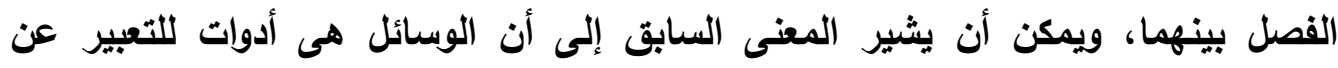

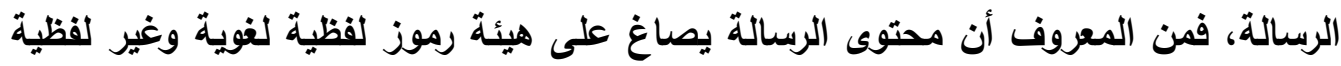
بصرية وحركية وتعبيرية تكون لغات خاصة، وتكون هذه الرموز تراكيب معينة تثكل الرسالة فى جانبها الحى أو الفيزيقى. وينظر إلى هذه الرموز على أنها وسائل فى حد ذاتها، فاللغة

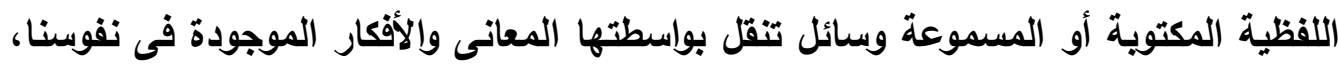
وهى فى نفس الوقت أدواتنا للتعبير عن هذه المعانى، وهى من ناحية أخرى تحتاج إلى وعاء يحملها كالكتاب والنشرات والجرائد وإلتسجيلات الصوتية - على شرائط كاسيت أو اسطوانات سمعية - والميكروفيش وحتى اسطوانات الكمبيوتر .

r. الوسائل حوامل للرسالة التعليمية:

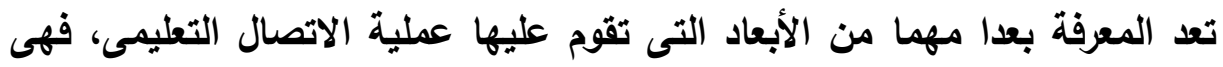
تثكل الرسالة التعليمية بما تشتمل عليه من حقائق ومفاهيم وقواعد وقوانين ونظريات ومهارات واتجاهات وقيم وميول. والمعرفة لابد لها من وعاء يحملها، وتأتى الوسائل كأوعية تحفظ المعرفة وتحملها، وتشكل هذه الأوعية الرسالة فى جانبها الحى الفيزيقى المادى. ولقد تريع الكتاب المطبوع على عرش أوعية المعرفة فترة طويلة، ولكن لم تعد لله هذه المكانة فى هي السنوات الأخيرة مع التطور العلمى الهائل الذى أسفر عن ظهور أوعية حديثة للمعرفة تتفوق عليه فى جواتب عديدة. وتصنف أوعية المعرفة إلى صنفين الأول يضم أوعية المعرفة الورقية 
أو المطبوعة ومن أمثلتها الكتب واللدوريات وإلنشرات والمجلات والجرائد، والثانى يضم أوعية المعرفة غير الورقية ومن أمثلتها أشرطة التسجيل الصوتى والمرئى والثرائح الفوتوغرافية والأفلام المتحركة والثابتة واسطوانات الكمبيوتر والمصغرات الفيلمية كالميكروفيلم والميكرفيش. ويطلق على أوعية المعرفة المستخدمة فى المواقف التعليمية اسم المواد التعليمية لأنها تحمل وتخزن المحتوى الدراسى المرتبط بالمقررات الدراسية بداخلها .

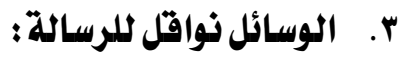
لا يفرق البعض بين حوامل الرسالة ونواقلها، وهولاء يعتبرون حوامل الرسالة هى الوسيلة تارة ويعتبرون نواقل الرسالة هى الوسيلة تارة أخرى فهناك من يعتبر مثلا جهاز عرض الشرائح وسيلة تعليمية، وهذا أمر يحتاج إلى مراجعة، فالجهاز لا يحمل الرسالة ولكنه ينقل الرسالة التى تحملها الثرائح ، والثابت أن بعض حوامل الرسالة لا تحتاج إلى أجهزة لنقل محتواها فى حين يتطلب البعض الآخر أجهزة معينة، وهنا لابد من التمييز بين مصطلح Hardware فالأول يشير إلى حوامل الرسالة وهى المادة التعليمية وإلثانى يشير إلى نواقل الرسالة وهى الأجهزة. ولا يمكن اعتبار الأجهزة فى حد ذاتها وسائل

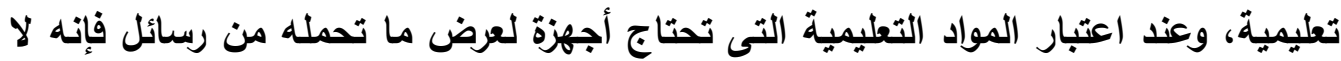
يمكن الفصل بين هذه النوعية من المواد ويين الأجهزة التى تحتاج إليها، فالأفلام على اختلاف أنواعها ومقاساتها مواد تعليمية إذا كانت موضوعاتها ذات صيغة دراسية، ومن الطبيعى أن يتعذر مشاهدتها ودراستها ما لم يكن هناك أجهزة لعرضها، وهنا يمكن القول أن مجال الوسائل التعليمية يضم المواد التعليمية والأجهزة معا. وإذا ما اعتبرنا مفردات اللغة غير لهات اللفظية كالصور والرسوم والإشارات وغيرها فإنتا يمكن أن ننظر إليها كوسائل وكأدوات لترميز الرسائل والتعبير عنها، وهى فى الوقت ذاته تحتاج إلى أوعية تحملها. وتعد المواد الطبيعية كالنباتات والحيوانات والأملاح والمعادن والصخور فى بيئاتها الحقيقية وإذا انتزعت منها أثياء وعينات ممثلة لنوعها، فيمكن استخدامها كمواد تعليمية فى مواقف الاتصال. وتثكل الملامـح الثلاثة السابق عرضها فى مجموعها مفهوم الوسائل التعليمية وتظهر دلالته ومعناه، وهى فى الوقت ذاته تحدد مكونات مجال الوسائل التعليمية، وعليه يتم تعريف الوسائل التعليمية بأنها : أدوات ترميز الرسالة وحواملها ونواقلها التى يمكن استخدامها فى 
مواقف الاتصال التعليمى من قبل المطم أو المتعلم أو كليهما داخل حجرات البحثوخارجها لتوفير الخبرات المباشرة ويدائلها لأحداث التعلم.

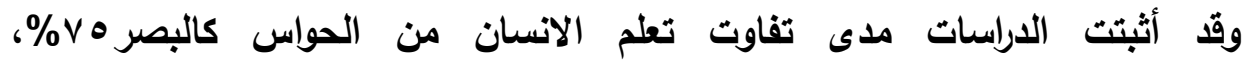

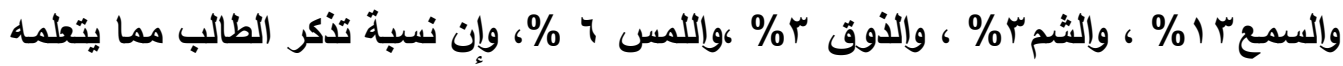

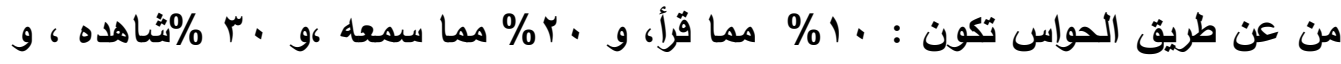

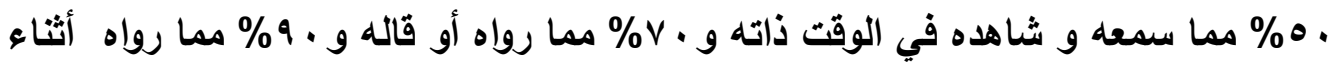

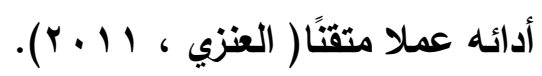

وهاذا يوكد على اهمية الوسائل التعليمية وضرورة استخدامها وتوظيفها فى المواقف التعليمية المختلفة بالفصل الدراسى وتوظيف جميع حواس المتعلم فى تلقى واستيعاب

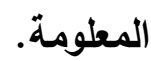

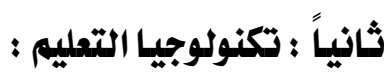
التكنولوجيا، هى ذلك المكون الذي غير حياة الناس على سطح الأرض و أعاد

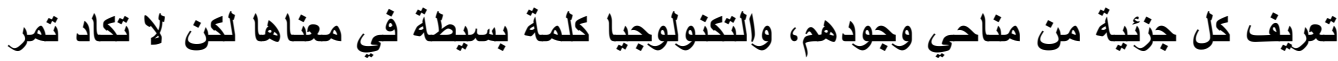
ساعة بل لحظة دون أن نستفيد من مزاياها ، واستعمال التكنولوجيا يكون فعالا وهادفا إذا تم ريطه بتصميم تعليمي- تعلمي واضح الأهداف والخطوات ويمكن تعريف التكنولوجيا أنها : التطبيق المنظم للمعرفة العلمية " أي تنظيم المعرفة من أجل تطبيقها في مجالات مثل تلائل

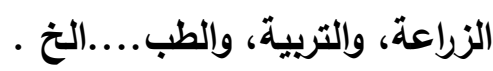

وتعرف تكنولوجيا التطليم بأنها " طريقه منهجية لتخطيط وتنفيذ وتقويم العطلية

التعليمية مستخدمة في ذلك كل الإمكانات المتوافرة البشرية والمادية لتحقيق أهداف محددة.

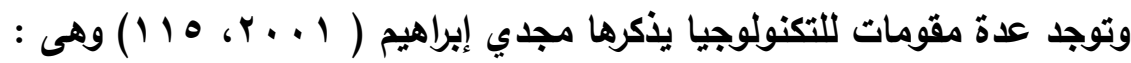
- ازدياد مستوى التعقيد للمشكلات التي تواجه الإنسان.

- أزياد الاستثمار غير المادي والاعتماد على الإلكترونيات وإمكاناتها الفائقة .

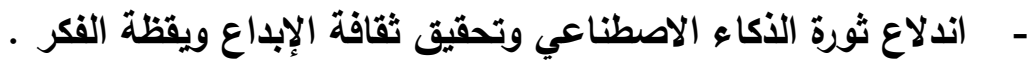

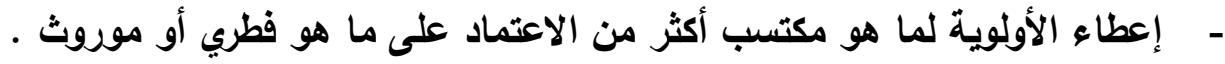




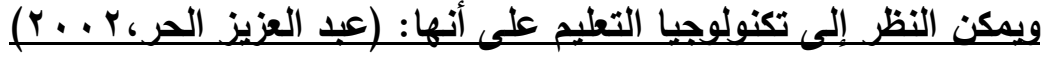

1 ـ تحليل المشكلات التعليمية. r ـ إيجاد حلول مبتكرة لهذه المشكلات. r ـ تجربة تلك الحلول لهذه المشكلات. ـ ـ تقويم فاعلية هذه الحلول في ضوء ما تحققه من الأهداف. ودمـج التكنولوجيا في الفصول الدراسية يؤدي إلى تحفيز الطلاب وردم الهوة التكنولوجية بين نمط حياتهم داخل المدرسة و خارجها. (أنيس ديوب، 17 ـ ب) وهذا يوضح أن تقنية التعليم لا تعني مجرد استخدام الوسائل والأجهزة والآلات الحديثة ولكنها تعني في المقام الأول طريقة في التفكير لوضع منظومة تعليمية " (بشير عبد

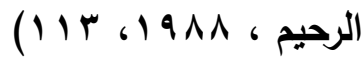

ويشير محمد الحيلة (Y . . F) إلى أن تقنيات التعليم تهتم بكل مصدر يسهل العملية

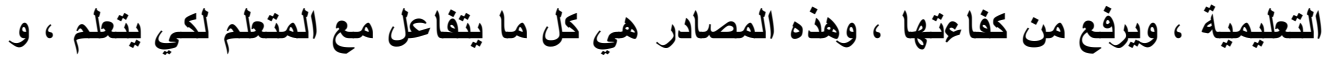
تثمل : الأفراد ، و الاستراتيجيات ، والمحتوى ، و الأدوات ، و الأجهزة ، و الأماكن ، وإلتجهيزات

وتلعب تقتيات التعليم دورًا هاماً في تطوير أدوار المعلم في العملية التعليمية منها التحول من التخطيط التقلياي للتعليم إلى التخطيط المنظومي، والتحول من الاهتمام المبالغ فيه لضبط النظام الصفي ، و التعليم الإلقائي إلى تصميم بيئة التعلم النشط ، و التعليم التعاوني، و الحرص على تحقيق كل تلميذ للأهداف التريوية المنشودة (حسن

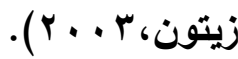

ومن أهم مبررات استخدام التقتيات الحديثة في التعليم انها تساهم في توفير بيئة تفاعلية وتقلل الإنفاق وتوفر موارد لا يمكن توفيرها بدونها ، ومن المميزات المعروفة لبعض

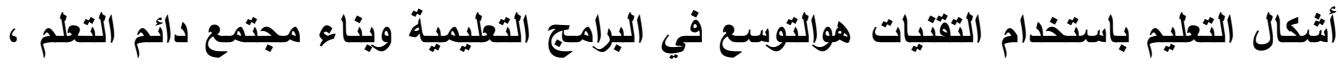
وتوفر أداة فعالة للنهوض بمستوى المعلمين باستمرار ، كما تساعد أساليب التعليم باستخدام التقنيات في التغلب على ندرة المعلمين خاصة بالمناطق النائية والفقيرة ، وتساهم في تلبية

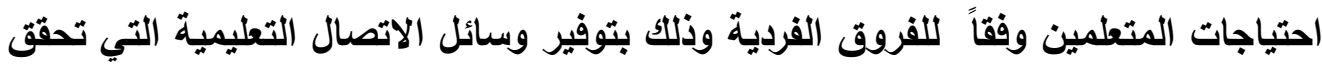
الفاعلية في التعليم وفق القدرات (مندور فتح الله ، ج . . ب ). 
ويؤكد (2011) Ramesh, N.I على أن التكنولوجيا لايها القدرة على توليد قدرا كبيرا

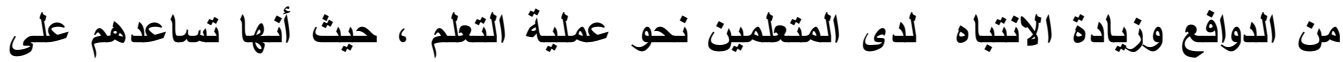
تحسين مشاركتهم وتفاعلهم مع دروسهم وأقرانهم ومعلميهم، وتعمل على تنشيط التعلم. فالتكنولوجيا لديها القدرة على خلق بيئة تعليمية صحية للمتعلمين ، والتأثثير بثكل إيجابي على تعزيز دافعية المتعلم وزيادة تفاعله في الصف لانها توفر تجربة تعليمية أكثر متعة

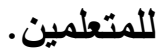

ومما سبق نجد ان تكنولوجيا التعليم في ظل هذا المفهوم تهتم بتصميم المناهج وتطويرها والخبرات التعليمية وتقويمها في ضوء أهداف محددة كما تعني بمشكلات الإفادة

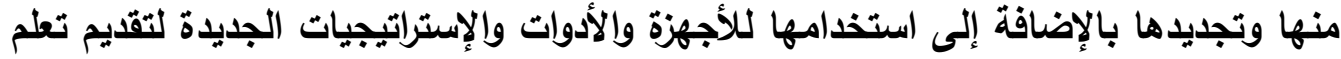

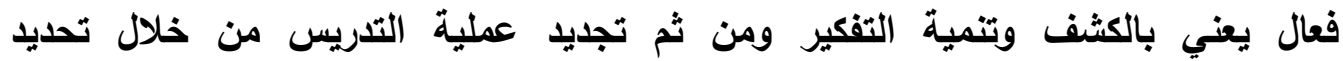
إستراتيجيات التدريس وتوصيف الأهداف بطريقة واضحة، يمكن قياس مدى تحقيقها، وكذلك بتحليل خطوات التدريس وطرق تعزيز استجابات التلاميذ ويعمليات التقييم المستمرة، ويتحاليل ما يرتد منها من معلومات تفيد في تخطيط التدريس مستقبلا ونرى محاولات كثيرة مثل برمجة التدريس، والتتريب الجماعي والفردي، والتدريس المصغر الذي يستخدم في إعداد المعلم.

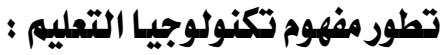
مرت الوسائل التعليمية بتسميات مختلفة إلى أن أصبحت علماً له مدلوله وتفريعاته

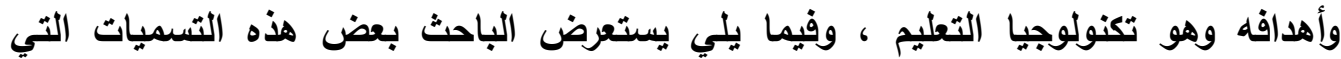

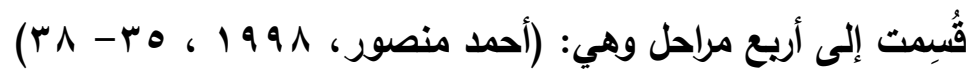

- المرحلة الأولى : وفيها تم تسميتها حسب الحواس ( وسائل بصرية ـ وسائل سمعية . وسائل سمعصرية ـ وسائل حسية أو إدراكية )

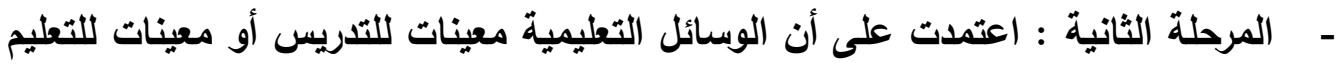

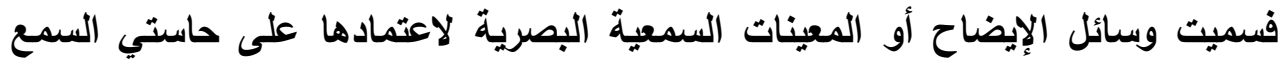

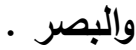
- المرحلة الثالثة : تم الاهتمام بالوسائل على أنها وسائل لتحقيق الاتصال فسميت وسائل الاتصال أو الوسائل التعليمية ، وفي هذه المرحلة أصبحت الوسائل التعليمية جزءاً متماً

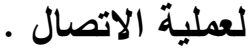


- المرحلة الرابعة : وهنا بدأ النظر إلى الوسائل التعليمية في ظل أسلوب المنظومات ، أي أنها جزء لا يتجزأ من منظومـة متكاملة وهي العملية التعليمية .

ومن هنا أدخل علم تكنولوجيا التعليم في ظل أسلوب المنظومات والذي تجاوز مفهوم الوسائل التعليمية في التعليم ، بل واهتم بالعملية التعليمية ككل منذ بدايتها في تحديد الأهداف التريوية حتى التقويم والاستفادة من التغذية الراجعة دائماً . السمات المميزة لتكنولوجيا التعليم :

في سباق تعدد تعاريف تكنولوجيا التعليم استخلص توفيق مرعي ومحمد الحيلة )

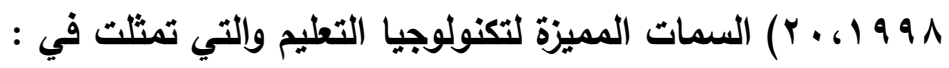
- النظامية : تكنولوجيا التعليم ليست مجموعة من المكونات والعناصر المبعثرة التي لا رابط بينها وإنما هي عملية نظامية تهذف إلى تحقيق المخرجات المطلوية مستخدمة الأسلوب

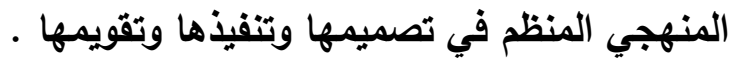

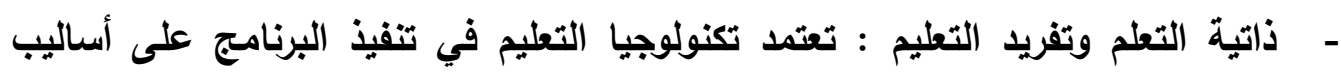
التعلم الأتية وتفريد التعليم من خلال استخدام الحقائب والرزم التعليمية ويرمجيات

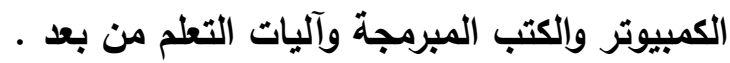
- - الكفايات وإتقان التعلم: إن البرامج القائمة على تكنولوجيا التعليم تتحدد فيهات الكيات الكفايات المطلوب إتقانها من المتعلمين ، تعد الكفايات مقياس المتعلم في النجاح ببلوغه مستوى الإتقان المطلوب فيها بغض النظر عن المدة الزمنية التي قضاها المتعلم في البرنامج أو مقدار المعلومات الذي استوعبه . - تسهم تكنولوجيا التعليم في إكساب الطالب المعلم المعرفة والمعلومات حول مـا هو حديث في محيط تدريسه لمواد التخصص . - تســـ تكنولوجيا الوسـائط المتعددة للطالب المعلم أن يعبر الحواجز الفاصلة بين فروع

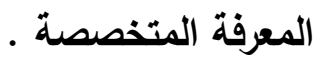
- - تتيح تكنولوجيا الوسائط المتعددة وسائط عديدة تنمى حاسـة الذوق والجمال لاى الطالب المعلم ، وتزخر شبكة المعلومات بمواقع كثيرة لأنشطة تريوية مختلفة تنمى القيم الجمالية 
- - تههم تكنولوجيا التعلبم بصورة فعالة في إكساب الطالب المعلم القدرة على توظيف معارفه عمليا، وتطبيقها لحل المشكلات . - تسـهم تكنولوجيا التعلبم في إكسـاب المعلم أنواع مختلفة من التفكير الابتكارى والناقد والعلمي كما يوفر دمج تكنولوجيا التعلبم من إنترنت وحاسب فرصا عديدة للإبداع. - تسهم تكنولوجيا التعليم وخاصة الانترنت في تمكين المعلم من نشر أفكاره واستقبال أفكار أخرى قد يستفيا منها في العملية التعليمية . - تساعد تكنولوجيا التعليم في تنمية مهارات المعلم في التواصل بينه ويبين التلاميذ ويبين

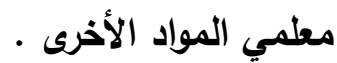

- توفر تكنولوجيا التعليم طرق جديدة لعرض المهارات التدريسية بصورة واضحة ومركزة . - - تسهم تكنولوجيا التعليم في تنمية القدرات الإبداعية لاى المعلم .

ثالثا : التربية الميلمانية التربية الميدانية (العملية) مرحلة هامة وضرورية من مراحل إعداد الطلاب المعلمين

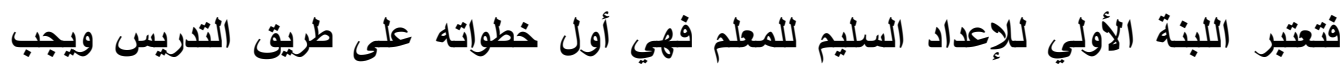
العناية بها ، وهى تلك الفترة الزمنية التي يُسمح فيها لطلبة وطالبات كلية التربية بالممارسة الحقيقية في الواقع لما درسوه من موضوعات مختلفة بالكلية تحت إشراف وتوجيه أعضاء هيئة تدريس من كلية التربية وكذلك مشرفين من الإشراف التربوى (التوجيه) أو من المؤهلين المتواجدين فى مدارس التطبيق. والخبرة الميدانية تغطي العمل الميداني، التدريب الوظيفي ، الدورات التدريبية وأشكال أخرى من التعلم من خلال التدريب والتعلم. والتى يكون هدفها تطوير الخبرة الميدانية للطالب للمعلم وذلك لما لها من تاثير على المستوى الاكاديمى وعلى ملى ملى المقررات التى يقوم بتدريسها والأخرى التى يدرسها في البرنامج التعليمى ـ وتتلخص أهمية

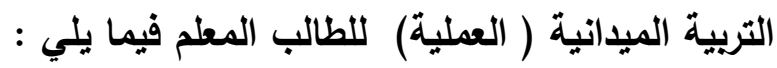

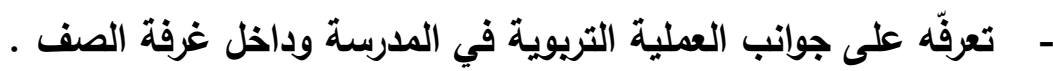
- - تهيئ الفرصة لترجمة المعرفة النظرية والمبادئ والأفكار التريوية إلى طرق تدريس فيس فعلية. - ت تيح الفرصة له ليتفهم طبيعة العمل الذي سيزاوله بعد التخرج . - تساعده على التكيف مع المواقف التربوية مما يساعد على إزالة الكثير من المخاوف التي تعتريه في باية تدريبه بالتدريج • 
- توفر فرص التدريب الموجه له لينمي لايه مهارات التدريس وتساعده على تكوين

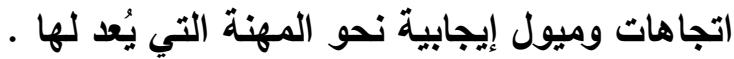
- تيح الفرصة أمامه للتعرف على قدراته الذاتية وكفاياته التدريسية والععل على تنميتها عن طريق الخبرة المباشرة ، وتنمية الحس المهني لايه .

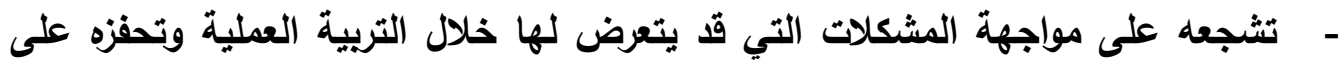
التفكير للتظلب عليها. - تمنحه الفرصة للتعرف على أنماط الطلاب وطرق تفكيرهم وميولهم ، ليكتسب بعض المهارات التي تمكنه من التعامل معهم . - - توفر الفرص أمامه لمشاهدة وتحليل نماذج مختلفة من مواقف التدريس التي يؤديها معلمون أكفاء ذوي خبرة طويلة. - تمكنه من المشاركة في الأنثطة المدرسية ومزاولته للمناشط التريوية لمادة تخصصه واكتسابه القدرة على الإثراف عليها.

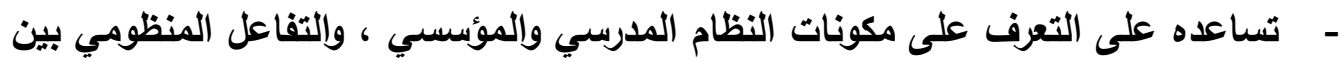
هذه المكونات . - تساعده على فهم حقيقي لقدراته وصفاته المهنية ، والعمل على تنميتها إلى أقصى حـ

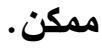
- الريط بين النظرية والتطبيق عن طريق وضع ما تعلمه الطالب المعلم في الجاتب النظري من المقرات الدراسية التي درسها بالكلية موضع التنفيذ .

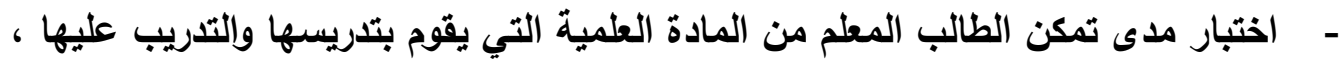

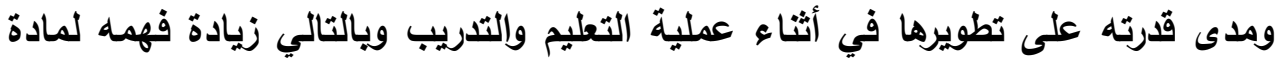
التخصص وزيادة اتجاهاته الايجابية نحوها. - احترام مهنة التدريس والخدمات التي تتعلق بها وتقدير العاملين بها وتكوين اتجاهات

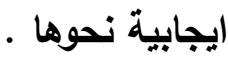
- تساعده على اكتساب الكفايات المهنية والتي تمكنه من أداء عملة بنجاح في مجال الصفات الثخصية والتدريس والتدريب وتقويم نمو الطلاب والتتوع في الأنثطة التطليمية

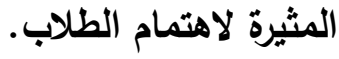


أههية التدريب الميلداذي للطالب المعلم :

يعد التدريب الميداني من الوسائل والأساليب التريبية الناجحة لأن المتدرب في برامج التدريب الميداني يعيش الواقع العملي بكل أبعاده النظرية والتطبيقية ويمارس نشاطه التدريبي بحماس ومعنوية عالية. ويشمل الإعداد التدريبي الميداني وضع الأهداف التدريبية المناسبة وإعداد الوسائل والأدوات التي تساعد على تنفيذ تلك الأهداف ويتم الإعداد للتدريب المبئي من قبل المدرب والمتدرب ، وعند التنفيذ توزع المهام اليومية على المتدربين وتعقد حلقات النقاش بعد كل يوم تدريبي لتقويم العمل وتعديل السلوك وتوزيع عمل اليوم التالي إذا

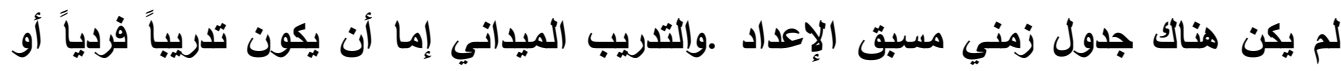

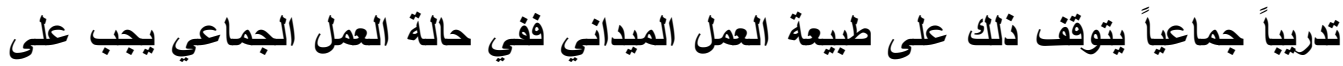
المتدرب معرفة دوره كاملاً ضمن فريق العمل وأن يلتزم بما حدد له من زمن في تنفيذ المهام الموكلة إليه وهو بذلك ينمي في نفسه علاقات التعاون وروح العمل الجماعي والانضباط . والإعداد للتدريب الميداني يتطلب تحديد برنامج عملي يشمل الخطوات التالية: أ ـ تحديد الأهداف التدريبية بمشاركة من المتدربين . ب ـ تحديد زمن التدريب من حيث زمن البدء في عملية التدريب والجدول الزمني لتتفيذ عملية التدريب.

ج ـ الإعداد الجيا لوسائل وأدوات وخامات التدريب وإعداد الأماكن الملائمة لممارسة التدريب. دـ ـ الإشراف والمتابعة من قبل مشرفي التدريب وتقويم العمل اليومي أثناء عملية التدريب. هـ ـ إعداد التقارير اليومية واطلاع المتدربين على تلك التقارير ومناقشة بنودها على أسس التس علمية تعتمد على ما إكتسبه المتدرب من حقائق ومفاهيم علمية مطلوب تطبيقها في العمل الميداني.

إيجابيات تكنولوجيا التعلبم فى تدريب الطلاب المعلمين بكلية التربية:

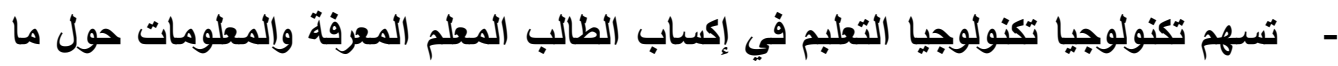
هو حديث في محيط تدريسه لمواد التخصص . - - تسمح تكنولوجيا الوسائط المتعددة للطالب المعلم أن يعبر الحواجز الفاصلة بين فروع المعرفة المتخصصة . 
- - تتيع تكنولوجيا الوسائط المتعددة وسائط عديدة تنمى حاسة الذوق والجمال لاى الطالب المعلم وتزخر شبكة المطلومات بمواقع كثيرة لأنثطة تريوية مختلفة تنمى القيم الجمالية . - - تسهم تكنولوجيا التعلبم بصورة فعالة في إكساب الطالب المعلم القدرة على توظيف معارفه عمليا، وتطبيقها لحل المشكلات . - - تههم تكنولوجيا التعلبم في إكساب المعلم أنواع مختلفة من التفكير الابتكارى والناقد والعلمي. كما يوفر دمج تكنولوجيا التعلبم من إنترنت وحاسب فرصا عديدة للإبداع. - - تهرم تكنولوجيا التعليم وخاصة الانترنت في تمكين المعلم من نشر أفكاره وإستقبال أفكار أخرى قد يستفيل منها في العملية التعليمية . - تساعد تكنولوجيا التعلبم في تنمية مهارات المعلم في التواصل بيذه ويين التلاميذ ويين

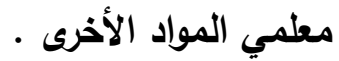

- توفر تكنولوجيا التعلبم نظم جديدة لعرض المهارات التريسية بصورة واضحة ومركزة .

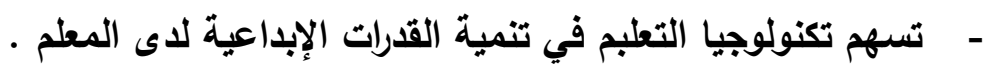

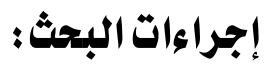
أولاً : الاختبار التحصيلي:

قام الباحث بإعداد اختبار تحصيلى يهدف إلى قياس المستوى التكنولوجى للطالب المعلم بكلية التربية بجامعة الملك خالد حيث قام الباحث بتجميع أكبر قر من الأسئلة التي تُغطى الجانب التقى فى محتوى مقرر الوسائل وتقتيات التعليم والمطلوب لتدريس المقررات

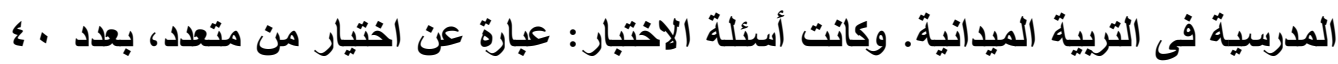
سؤال ، في كل سؤال جذر تعقبه أربع اختيارات أو بدائل. وفيما يتعلق بصياغة السؤال من

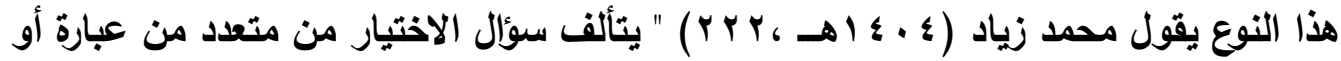

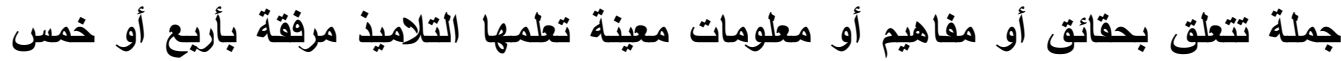
إجابات يجب على التلميذ أن يختار أحدها لإتمام معنى الجملة أو العبارة العامة في أول السؤال " ويضيف أن هذا النوع يعتبر من أشهر الاختبارات الموضوعية وأوسعها انتشاراً

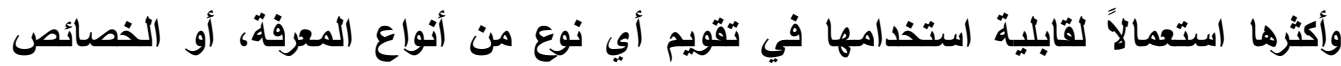

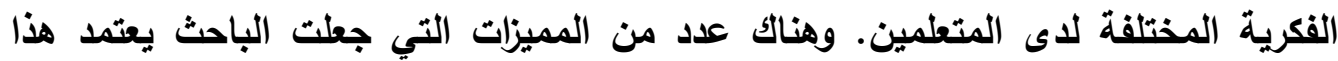
النوع من الاختبارات في تجريته ومن تلك المميزات ما ذكره فؤاد أبو حطب وسيد دـ عثمان 


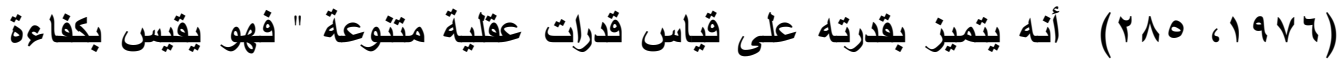

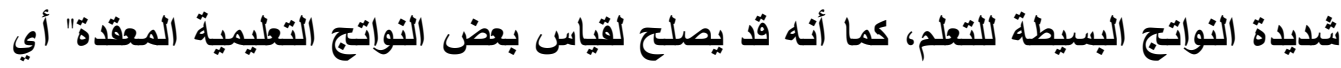

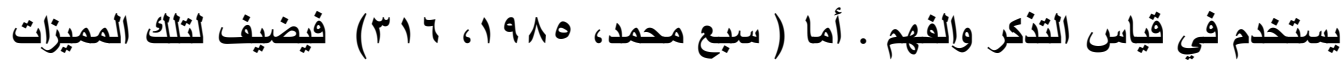
أنه يمكن الفاحص من قياس مدى تحقيق جميع الأهداف التريوية لاسيما ما يتعلق بالعمليات

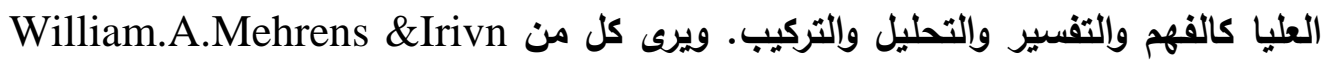
(1978, 279") إنه بالإضافة إلى إستخدام الاختبار من متعدد الاختيارات لقياس التذكر فإنه يمكن قياس قدرة الطلبة على استنتاج الأسباب والتدرب على الحكم على الأشياء والتعبير عن

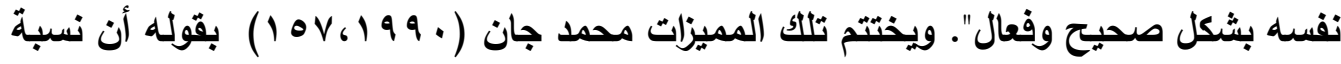
التخمين فيه أقل من غيره من أنواع الاختبارات الموضوعية الأخرى لأن هناك أريعة اختيارات،

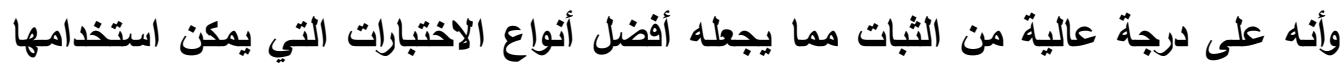
لقياس نتائج التحصيل الدارسي إضافة لاحتوائه على عينة كبيرة من المحتوى الدراسي مما لاسي يرفع درجة صدقه إلى حد كبيز، فضلاً عن موضوعية التصحيح وعلم تأثر درجات الاختبار بعوامل أخرى خارجة عن الاختبار نفسه، وينمي القدرة على حل المشكلات، كما أنه يمكن التحكم في مستوى صعويته بوضع اختيارات متجانسة يصعب التمييز بينها لغير الطالب المستعد للاختبار.

تحديد الهدف من الاختبار: يهذف الاختبار إلى قياس تحصيل عينة من طلبة البكالوريوس في كلية التربية بجامعة الملك خالد ، في الجانب المعرفي للمستوى التكنولوجى مله للطالب وفقاً لمستويات بلوم المعرفية والتي تُُطى الجانب التقنى المطلوب لتدريس المقررات المدرسية فى التربية الميدانية بعد دراستهم لمقرر الوسائل وتقنيات التعليم. صياغة مفردات الاختبار: تم تحديد نمط الاختبارات الموضوعية لإعداد الاختبار وتم استخدام مفردات من نوع (الاختيار من متعدد)، وتم مراعاة الثروط اللازمة لها ، حتى يكون الاختبار بصورة جيدة، وفى ضوء محتوى مقرر الحاسب في التعليم تمت صياغة مفردات الاختبار . إعداد جدول المواصفات للاختبار: اقتضى تحديد المواصفات الأولية للاختبار، صياغة الأهداف الإجرائية، وتحليلها وتنظيمها، ووضعت مواصفات الاختبار وفق المستويات 
المعرفية لبلوم، وعلى هذا الأساس تم تحديد المفردات التي ترتبط بكل مستوى من مستويات الأهداف المعرفية لبلوم المراد تحقيقها لكل موضوع.

طريقة تصحيح الاختبار : يحصل الطالب على درجة واحدة على كل مفردة يجيب عنها إجابة صحيحة، وصفر على كل مفردة يتركها أو يجيب عنها إجابة خاطئة، ويذلك تكون

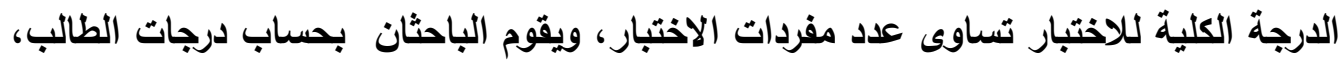
وذلك فور انتهائه من الإجابة على أسئلة الاختبار. التحقق من صدق الاختبار : تم التحقق من مدى تمثيل الاختبار للأهداف المحددة له،

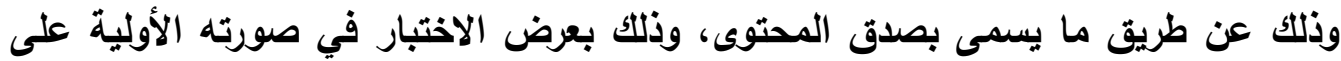

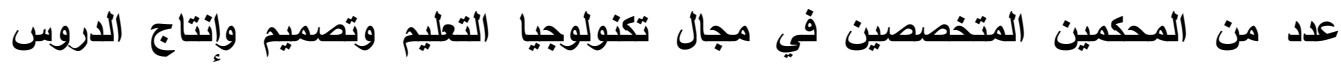
والبرمجيات التعليمية ، بهدف الاسترشاد برأيهم ، وقد أوصى السادة المحكمين ببعض

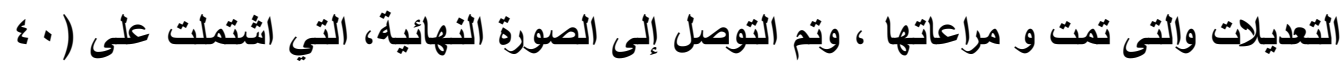

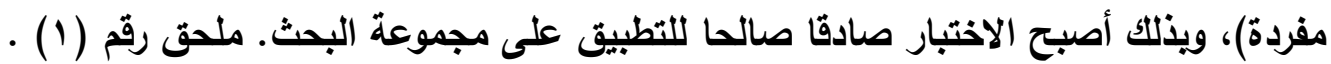

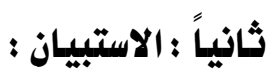
نظرًا لاستشعار الباحث أن الضعف في المستوي التكنولوجى للطلاب أنفسهم، مما جعله يتقصي عن أسباب هذا الضعف من وجهة نظر الطلاب باعتبارهم أساس المشكلة، ولذلك كاتت الأداة الثانية من أدوات البحث وهيالاستبيان. 1 - تصميم الاستبيان : صمم الباحث الاستبيان من (0) عبارة، وهى تهدف إلي توضيح رأي الطلاب عن أسباب الضعف التكنولوجى لايهم أثناء تدريس مواد التخصص بالمرحلة

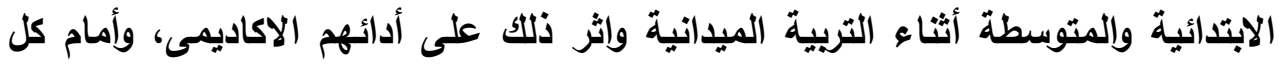
عبارة ثلاثة اختيارات (أوافق بشدة، أوافق، لا أوافق) وتقابلها الدرجات (T، Y، I I) علي الترتيب. r- الهذف من الاستبيان: يهدف إلى تعرف أسباب الضعف في المستوي التكنولوجى من وجهة نظر الطلاب باعتبارهم أساس المشكلة، وتوضيح أيهم عن أسبابه لايهم أثناء تدريس مواد التخصص بالمرحلة الابتدائية والمتوسطة أثناء التربية الميدانية وائز ذلك على أدائهم الاكاديمى. 
r- حساب صدق الاستبيان: تم عرض الصورة الأولية للاستبيان على المتخصصين في مجال علم النفس، والمناهج وطرق التدريس، وتكنولوجيا التعليم بهدف الاسترشاد برأيهم ، وتم إجراء التعديلات التي اقترحها المحكمن مثل تعديل الصياغة اللغوية لبعض الكلمات،

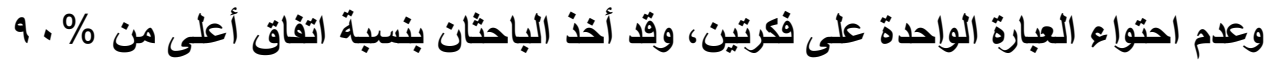
ع - حساب ثبات الاستبيان: استخدم الباحثان معادلة " ألفا كرو نباخ" لحساب التناست الاخلي لعبارات الاستبيان وثباته، وذلك عن طريق حساب معامل الارتباط بين مجموع

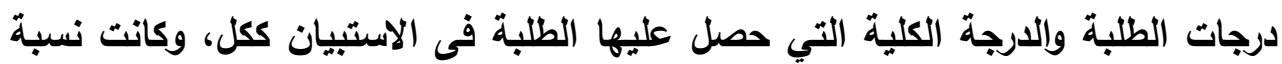
معامل ثباته ككل بلغت ( ع V. •) وهو معامل ثبات مقبول ومناسب مما يدل على صلاحية الاستبيان للاستخدام. ويعد تتفيذ آراء المحكمين و حساب الصدق وإلثبات أصبح الاستبيان في صورته النهائية القابلة للتطبيق ملحق رقم (Y). ثتائج البحث :

أولا : تتائج تطبيق الاختبار التحصيلى : للإجابة عن السؤال : ما مدى ضعف التكنولوجى لاى الطالب المعلم بكلية التربية بجامعة الملك خالد؟. بع. تكون الاختبار من ·ـ مفردة من نوع الأختيار المتعدد ، بعد التأكد من ثباته وصلاحيته وتم تطبيقه على مجموعة البحث وهم مجموعة من طلاب المستوى الثامن بكلية التربية وهو المستوى المحدد للتربية الميدانية عددهم ·ب طالب ، ويعد ذلك قام الباحث بتصحيح الاختبار في ضوء نموذج الإجابة مع توزيع الدرجات المتفق عليها والتوصل إلى مستوى التمكن التكنولوجى للطلاب. وكانت نتائج الاختبار كما يلى :

\begin{tabular}{|c|c|c|}
\hline النسبة & عدد الطلاب & الارجة \\
\hline صفر \% & صفز & من 1- \\
\hline صفر\% & صفر & من · - 'r \\
\hline$\% 7 V$ & $r$. & من ·r · r \\
\hline$\% \mu r$ & 1. & من · r-· \\
\hline$\% 1 \ldots$ & $r$. & المجموع \\
\hline
\end{tabular}


ومن الجدول السابق يتضح تدني مستوى المهام المعرفية والأدائية للطلاب المعلمين حول تكنولوجيا التعليم، يث بلغت نسبة المتفوقين بr\% فقط ، والنسبة الأغلب من الطلاب كانت متوسطة حيث بلغت Vฯ\% ـ وهذه النتيجة تتفق مع أغلب الدراسات السابقة

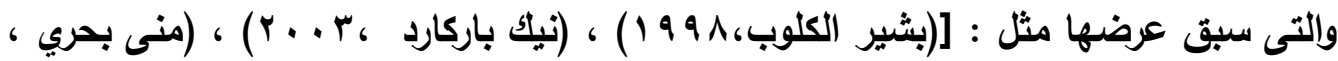

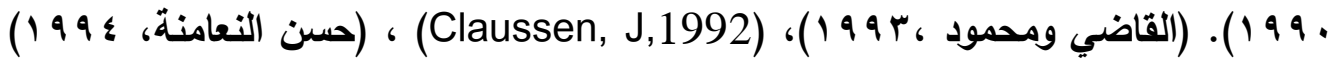

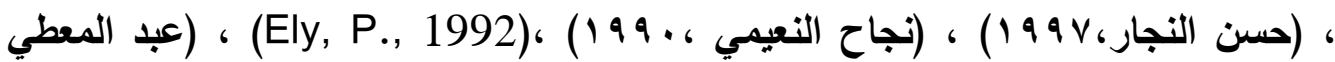
الصباغ ، ؛ 99 1 )] والتى اهتمت بموضوع تنمية مهام المعلمين في مستحدثات تكنولوجيا التعليم والتي أكلات جميعها على الحاجة لتدريب ورفع كفاياتهم نحو مستحدثات تكنولوجيا التعليم وتوظيفها في العملية التعليمية، وتطوير الأداء المهني لايههم. ومواكبة التطور واستخدام بيئات تعلم الكترونية تتميز بالتفاعل وتتمركز حول النظريات التربوية الحديثة، والمفاهيم الجديدة من مستحثثات تكنولوجيا في التعليم. وضرورة إدراج التدريب على تكنولوجيا التعليم كمنطلب أساس ضمن برامج تنمية قدرات الطلاب المعلمين. وكذلك مهارات التعامل مـع شبكة الانترنت، وعقد المؤتمرات وورش العمل، لزيادة الوعي بمستحدثات تكنولوجيا التعليم ومتابعة كل جديد في هذا المجال. ثانياُ : نتائج تطبيق الاستبيان : للإجاية عن السؤال : ما أثر ضعف التمكن التكنولوجى لاى الطالب المعلم بكلية التربية بجامعة الملك خالد على أدائه الاكاديمى في التربية العملية؟. 
ضعف التمكن التكنولوجى لدى الطالب المعلم بكلية التربية بجامعة الملك خالد....

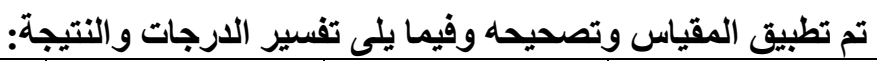

\begin{tabular}{|c|c|c|c|c|c|c|c|}
\hline \multicolumn{2}{|c|}{ لا أوافق } & \multicolumn{2}{|c|}{ أوافق } & \multicolumn{2}{|c|}{ أوافق بشدة } & \multirow[b]{2}{*}{ العبارات } & \multirow[b]{2}{*}{ p } \\
\hline النسبة & الأصوات & النسبة & الأصوات & أنسبة & الأصوات & & \\
\hline $1 \pi$ & $\varepsilon$ & r. & 7 & TV & $r \cdot$ & 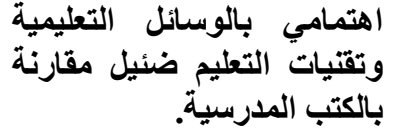 & 1 \\
\hline 17.7 & 0 & $r q . V$ & $\Lambda$ & $07 . V$ & IV & 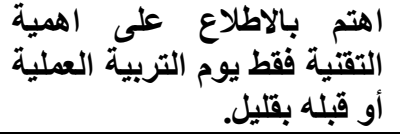 & r \\
\hline 1. & $r$ & $r$. & 9 & 7. & 11 & 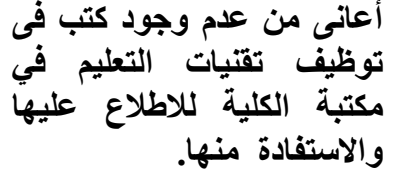 & $\mu$ \\
\hline $7 . V$ & r & 17.7 & 0 & $V 7 . V$ & $r \mu$ & 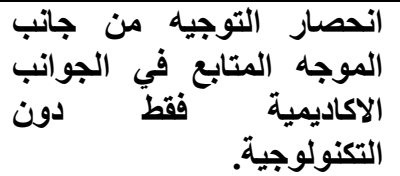 & $\varepsilon$ \\
\hline $7 . V$ & r & r ..V & $\Lambda$ & 97.7 & r. & 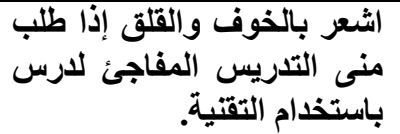 & - \\
\hline$r . r$ & 1 & r.r & $\varepsilon$ & $\Lambda r . \varepsilon$ & ro & 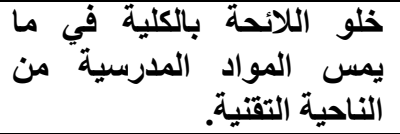 & 7 \\
\hline صفر & صفر & Y ..V & $\Lambda$ & Vr.r & YY & 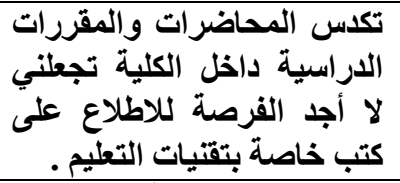 & . \\
\hline 17.7 & 0 & Y ..V & $\Lambda$ & $07 . V$ & IV & 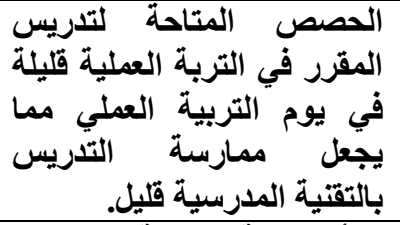 & $\Lambda$ \\
\hline$r . r$ & 1 & $1 \% . r$ & $\varepsilon$ & $\wedge r . \varepsilon$ & ro & 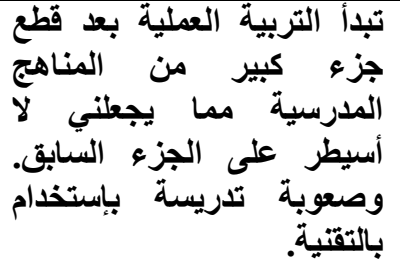 & 9 \\
\hline$r . r$ & 1 & r. & 9 & 79.8 & r. & 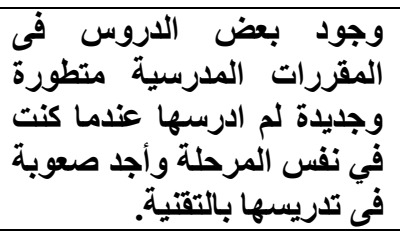 & 1. \\
\hline
\end{tabular}


ضعف التمكن التكنولوجى لدى الطالب المعلم بكلية التربية بجامعة الملك خالد...

\begin{tabular}{|c|c|c|c|c|c|c|c|}
\hline $7 . V$ & $r$ & 17.7 & 0 & $87 . V$ & $r r$ & 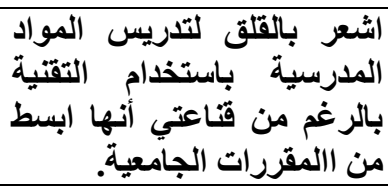 & 11 \\
\hline $7 . V$ & r & r ४.V & $\Lambda$ & 77.7 & $r$. & 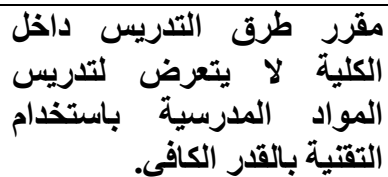 & $1 Y$ \\
\hline $1 T$ & $\varepsilon$ & r. & 9 & $7 V$ & $r$. & بالكلبة إن تضادة بمديمى للائحة الإعداد المواد & 14 \\
\hline$r \cdot . \Lambda$ & 10 & r. & 1. & r..$q$ & YI & أجد ثقة في إنتي ملم بالتقنية & 18 \\
\hline r.r & 1 & $\varepsilon$. & ir & $70 . V$ & IV & 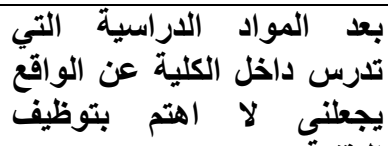 & 10 \\
\hline
\end{tabular}

من الجدول السابق ويعد تصحيح الاستبيان ويناء على لأى الطلاب كانت النتيجة

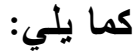

1- كان أى الطلاب في اهتمامهم بالوسائل التعليمية وتقتيات التعليم ضئيل مقارنة بالكتب

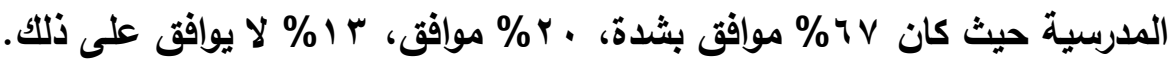

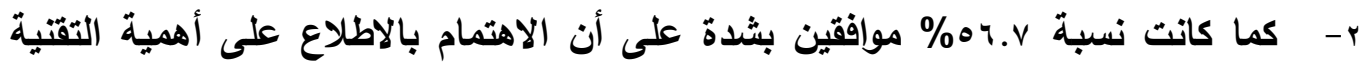

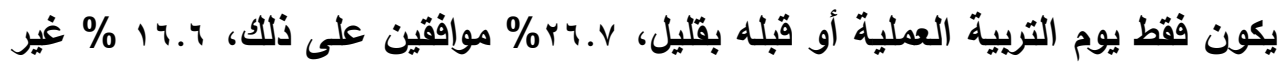
مواققين.

r- وكانت موافقة الطلاب بثدة على وجود معاناة من عدم وجود كتب فى توظيف تقتيات

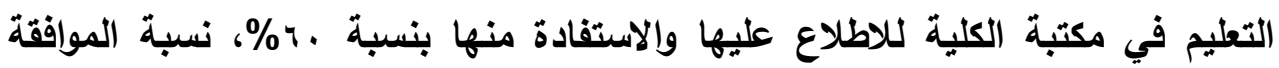

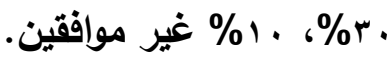
ء - أما عن انحصار التوجيه من جانب الموجة المتابع على الجوانب الثكلية والجوانب

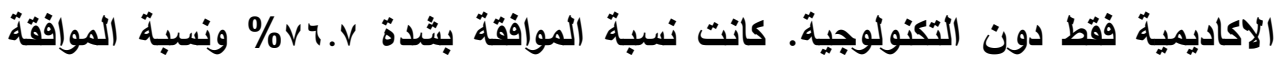

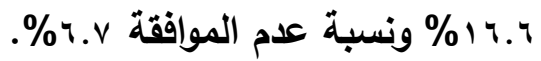
ه- أما عن شعور الطلاب بالخوف وإلقلق إذا طلب منهم التدريس المفاجئ لارس بالمقرر

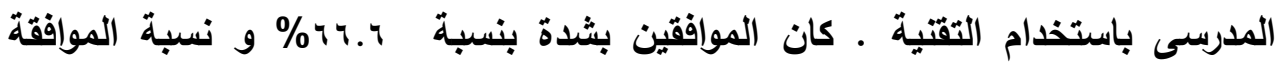

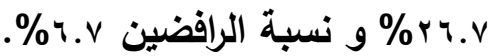


צ- وكان ؛.r^\% موافقين بثدة على خلو اللائحة بالكلية في ما يمس المواد المدرسية من

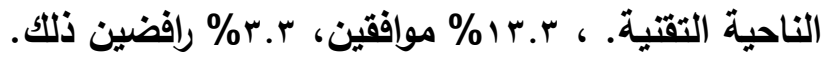
- v أما عن تكدس المحاضرات والمقررات الدراسية داخل الكلية والتى لا تجعهم يجدون الفرصة للاطلاع على كتب خاصة بتقنيات التعليم ـ فنسبة الطلاب الموافقين بشدة

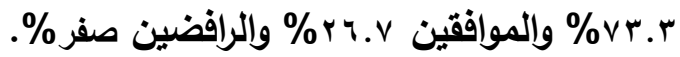
^- وعن أيهم فى أن الحصص المتاحة لتدريس مادة التخصص في التربة العملية قليلة وينحصر في يوم التربية العملي مما يجعل ممارسة التدريس لمواد التخصص بالتقتية

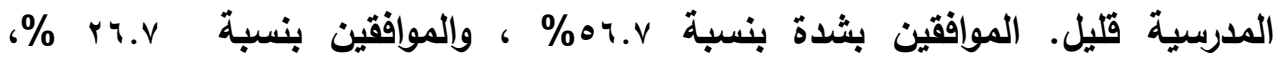
والرافضين بنسبة 9- وكان رأى الطلاب عن بأ التربية العملية بعد قطع جزء كبير من مقررات مواد التخصص مما يجعلني لا أسيطر على الجزء السابق.واجد صعوية فى تدريسه بالتقتية. موافقون

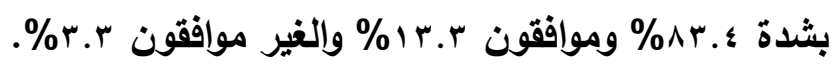

•- - وكان رأى الطلاب في وجود بعض الدروس في مواد التخصص متطورة وجليدة لم يتم دراستها عندما كانوا في نفس المرحلة ومن الصعب تدريسها بالتقتية. كانت نسبة ودية الموافقة عليها بشدة v. r. 1 - وعن شعور الطلاب بالقلق لتدريس مواد التخصص باستخدام التقتية بالرغم من قناعتهم

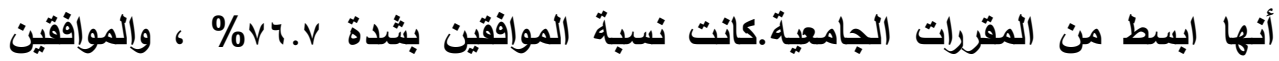

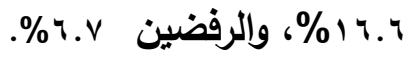

rا - وعن رأى الطلاب في أن مادة طرق التدريس داخل الكلية لا تتعرض لتدريس مواد

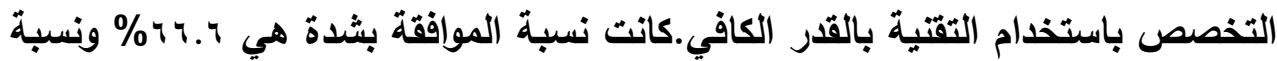

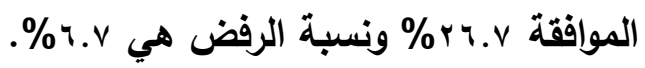

rا - وعن رأيهم فى انه يجب إن تضاف للائحة الإعداد بالكلية مادة بمسمى المواد المدرسية

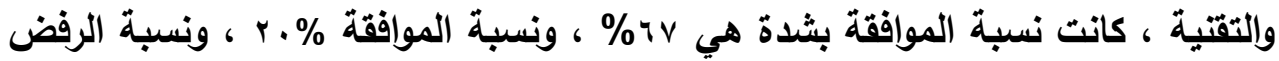


؛ ا-وعن رأيهم فى الثقة بالإلمام بالتقتية وتوظيفها لتريس مواد التخصص بالتربية

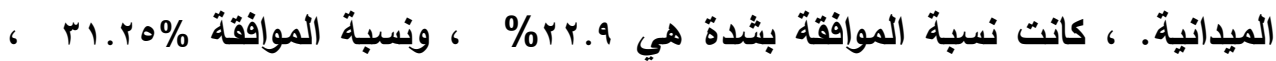

$$
\text { ونسبة الرفض هي ^. .r\%. }
$$

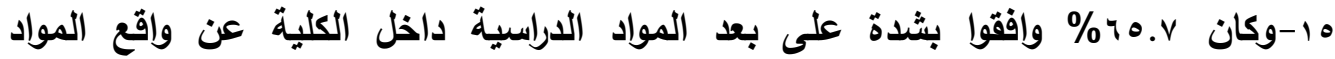
المدرسية، . ؛\% وافقوا فقط، r.ب\% رفضوا هذا البند.

ويتضح مما سبق أن هذه النسب تكثف عن التذني في واقع استخدام وتوظيف تقنيات التعليم وخاصة الحديثة منها بالمدارس أثناء التدريب الميدانى الأمر الذي يحتم ضرورة الاهتمام بتطوير واقع استخذامها فى التعليم. كما يتضح أن نسب توظيف المطلم

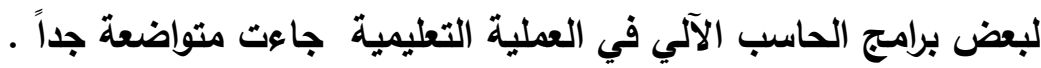
كما يتضح من الأراء جود مشكلات تخص الطلاب انفسهم وتعيق استخدامهم للتقنية

1- عدم الاهتمام بالوسائل التعليمية وتقتيات التعليم مقارنة بالكتب المدرسية.

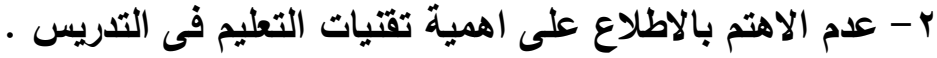
r- عدم وجود كتب فى توظيف تقنيات التطليم في مكتبة الكلية للاطلاع عليها والاستفادة منها. ؛ - الثعور بالخوف والقلث عند تدريس المواد الدرسية باستخدام التقنية. بالرغم من قتاعتهم أنها ابسط من المقررات الجامعية. ه- بعد المواد الدراسية التي تدرس داخل الكلية عن الواقع المدرسى يجعهم لا يهتموا

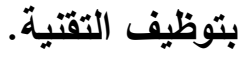
كما يتضح وجود بعض مشكلات خارجية لا تخص الطلاب ويعيدة عن إرادتهم ولكن تعيق استخدامهم للتقتية وهى : 1 - انحصار التوجيه من جانب الموجه المتابع في الجوانب الاكاديمية من تحضير للادرس وحضور الحصص.فقط دون التكنولوجية. r - خلو اللائحة بالكلية في ما يتعلق المواد المدرسية من الناحية التقنية.

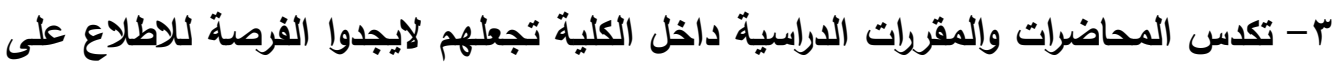

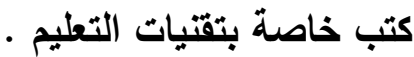


ع - قلة الحصص المتاحة لتدريس المقر في التربة العملية في يوم التربية العملي مما يجعل ممارسة التدريس بالتقتية المدرسية قليل.

ه-تبدأ التربية العملية عادة بعد قطع جزء كبير من المناهج المدرسية مما يجطهم لا لالفية يسيطرو على الجزء السابق. ويجدوا صعوية فى تدريسة بإستخدام بالتقنية. צ- وجود بعض الدروس فى المقررات المدرسية متطورة وجديدة لم يتم دراستها عندما كانوا في نفس المرحلة ويهذا يجدوا صعوية فى تدريسها بالتقتية. V- مقررطرق التدريس داخل الكلية لا يتعرض لتدريس المواد العدرسية باستخام التقتية

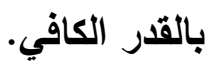
^- عدم إهتمام للائحة الإعداد بالكلية بالتقنية بالقدر الكافى وعدم وجود مادة بمسمى المواد المدرسية والتقتية .

وسوف يقوم الباحث بتقيم حول ومقتراحات فى مقترحات وتوصيات البحث للتظلب على هذه المشاكل سواء ما يخص للطالب او تلك التى لا دخل له هله ولعل هذه النتائج توضح جليا ضرورة عقد دورات تدريبية للطلاب على استخدام التقتيات الحديثة ويرامج الحاسب الآلي وكيفية توظيفها واستخذامها في العملية التعليمية. كما تثير هذه النسب إلى حاجة هؤلاء الطلاب إلى التدريب على استخدام الأجهزة والمواد التعليمية . التهيز

وريما يرجع السبب في هذه النسب المتننية لأمرين أما عدم توفر هذه الوسائل في المدارس أو توفر هذه الوسائل في المدارس ولا يستخدمها المعلم لمجموعة من الأسباب منها

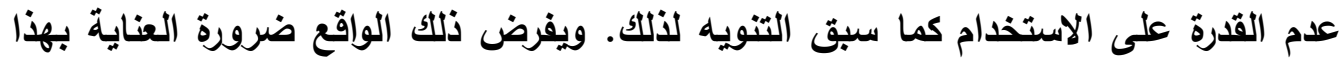

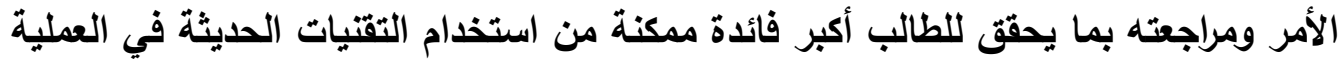
التعليمية .وتتفق هذه النتيجة مع نتائج بعض الداسات التي أظهرت وجود عوائق وصعويات التئي Bitter, G, G تحد من استخدام التقتيات الحديثة في العملية التعليمية مثل : دراسية (1985) والتي أكلت على أن أكثر الصعويات التي تواجه توظيف الحاسب في التطليم في

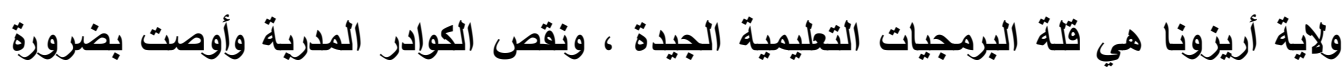

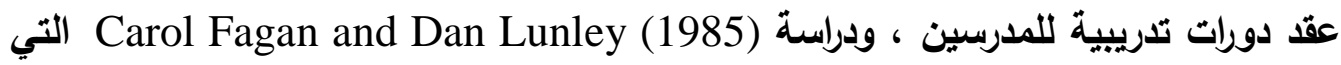


يؤكد فيها بضرورة تصميم وتوفير الدورات التدريبية للمعلمين بصورة تثفق مع

خلفياتهم العلمية باعتبارها من أهم طرق التقلب على عدم توظيف التقنية في التعليم . ثالثاً : للإجابة عن السؤال : ما الحلول المقترحة لمعالجة هذا الضعف التكنولوجى للدى الطالب المعلم

\section{بكلية التربية بجامعة الملك خالد اثناء التربية الميلدانية؛.}

لتحقيق التطوير المرغوب في تدريس مواد التخصص بالمرحلة الابتدائية والمتوسطة من خلال استخدام تكنولوجيا التعليم اثناء التربية الميدانية ، لابد أن تؤخذ بعين الاعتبار جميع الجوانب المادية ، والنفسية ، والمعرفية ، والمهارية اللازمة لاستخدام التقتيات التعليمية والحاسب الآلي واللازمة لتفيذ أنشطة العملية التعليمية ، والتي يجب أن تطور على التى أساس دراسات دقيقة تصف الواقع الفعلي لهذه الجوانب في المدارس الابتدائية والمتوسطة ، ولتوفير بيانات عن الإمكانات المتوفرة ، و المعوقات الفعلية ، والتي في ضوئها يمكن التوصل إلى نتائج نمثل منارات لرسم خطط التطوير التريوي المثمر . وفيما يلى بعض الحلول المقترحة لمعالجة الضغف التكنولوجى لاى الطالب المعلم بكلية التربية بجامعة الملك خالد اثناء التربية الميدانية

1. اهتمام التوجيه من جاتب المشرف المتابع بالجوانب التقتية بجانب النواحي الأكاديمة . r. تخصيص سنة دراسية كاملة لتدريب الطالب المعلم ويلء التربية العملية مع بداية العام الدراسي فى العام الاخير بلد من فصل دراسى واحد فقط.

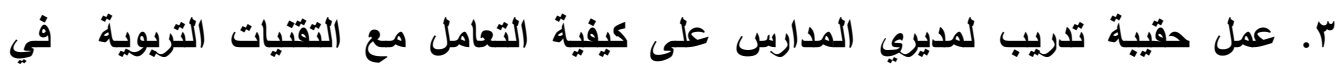
المدارس وما هى التقنيات المتوفرة بالمدرسة والتي يمكن أن تساعد الطالب النعلم على هيل

$$
\text { توظيفها في الارس اثناء تدريبه الميدانى. }
$$

؛. أن يتم تنظيم فترة المشاهدة فى التربية العملية وفيها يقوم المشرف فى التربية العملية بعرض نماذج لأسئلة تحريرية ذات صياغات ضعيفة وصياغات جيدة ويتم تقويم وتحليل هذه الأسئلة من قبل الطلاب بواسطة المعيار الذى يوزع عليهم (استمارات التحليل). ه. أن يتم التدريب على مهارة وإحدة من مهرات التدريس فى كل أسبوع أثناء فترة التربية العملية، وذلك بأن يوجه المشرف على التربية العملية الطلاب إلى مصدر معين ( كتاب

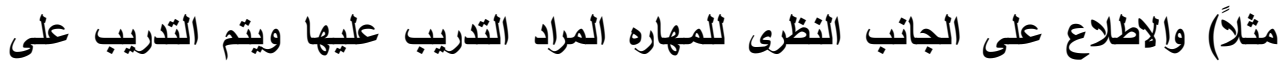
الجانب العملى لهذه المهارة بعد مناقشة الجانب النظرى ، على سبيل المثال يقرأ الطلاب 
المعلمين موضوع قواعد صياغة أسئلة المقال ثم يتم التدريب على انتاج أسئلة مقال تتنقى وقواعد الصياغه التى سبق وأن قرأها الطلاب المعلمين.

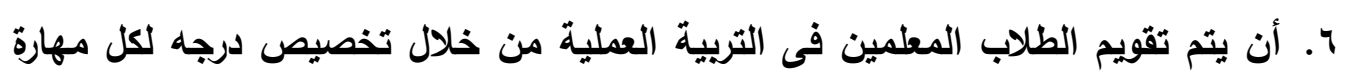

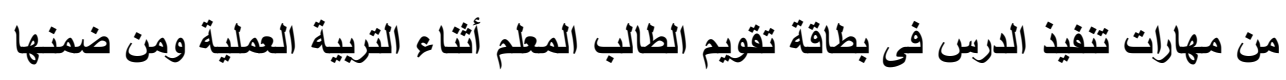

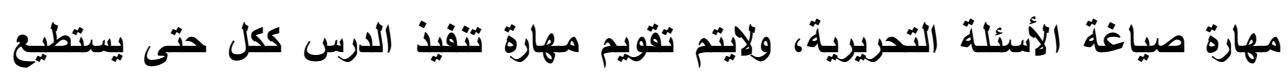
الطالب والمشرف الاهتمام بجميع المهارات المكونة لمهارة تنفيذ الدرس.

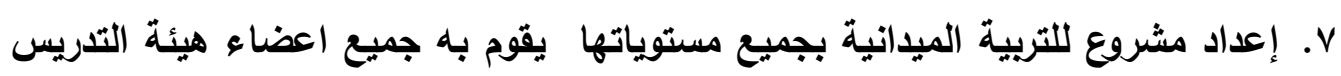

$$
\text { ويتمثل فى التالى: }
$$

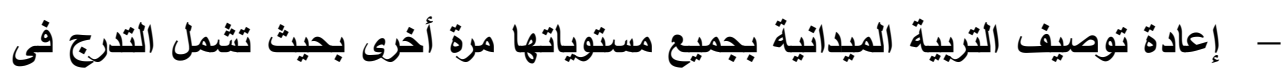

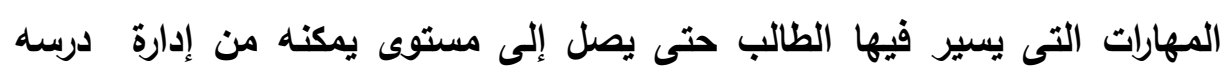

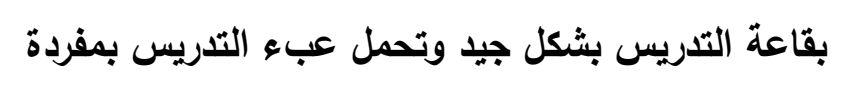

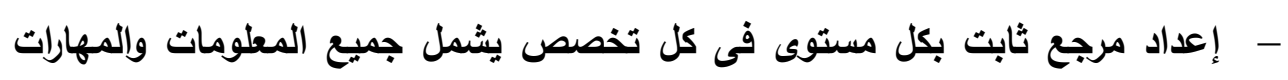

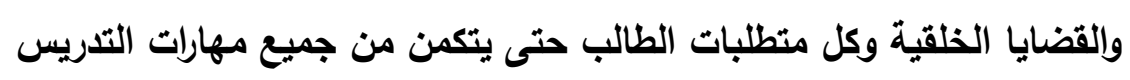

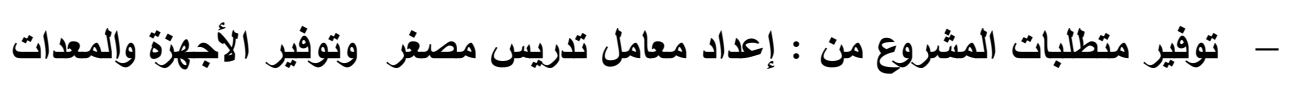
حسب كل تخصص.

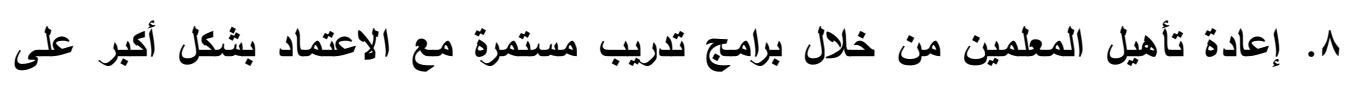

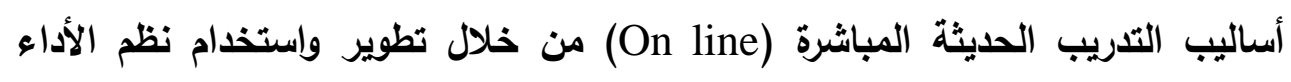

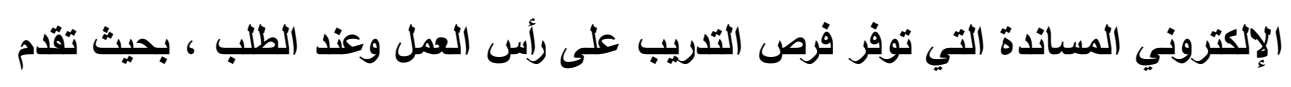

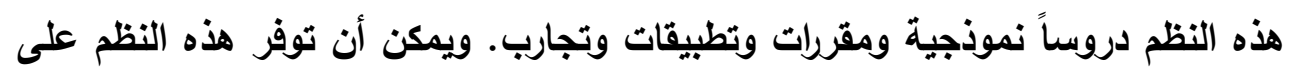

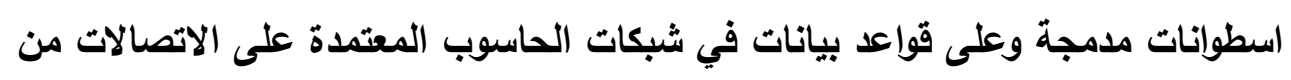

بعد.

9 9. ان يتم ومنذ السنة الأولى تدريس المقررات في مادة التخصص والمقررات الأخرى فى ايام

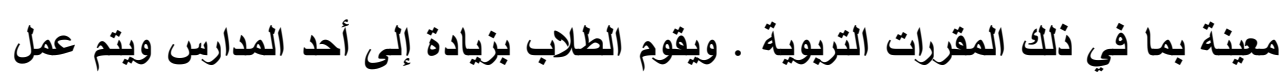

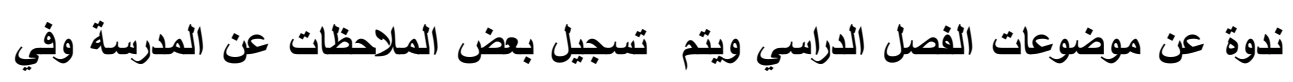

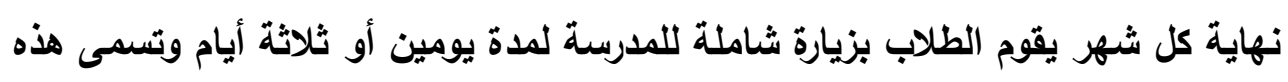
بالتربية العملية المتصلة. بحيث لا يدرس المواد التريوية كمواد منفصلة أو كمقررات 
دراسية فقط ولكن توظف في إعداده كمعلم للتعامل مع الطلاب ومراعاة الفروق الفردية بينهم. • 1.أن يعتمد انتقال الطلاب المتلربين من صف دراسى إلى آخر على أدائهم العام ومدى

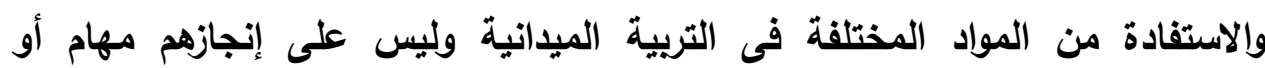
اختبارات معينة للمادة او المقرر الدراسى. وهذا يزيد من فهم الطلاب للواقع التعليمي ويالتالي يزيد من قدرتهم المهنية بعد ذلك .

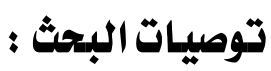

في ضوء النتائج السابقة يمكن تقيم التوصيات التالية : - ضرورة عقد دورات تدريبية لأعضاء هيئة التدريس بكلية التربية في التعليم العام تختص فئس بكيفية استخدام التقنيات الحديثة في العملية التعليمية. - - لابد من إدخال التقنيات الحديثة في مدارس التعليم العام مواكبة مع تطور المناهج فلابد العيد أن يقترن تطور المناهج مع تطور التقتيات المستخدمة في التعليم .

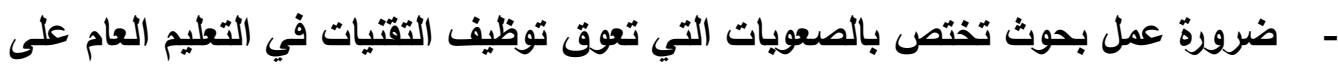
مستوى المملكة . - عمل حلقات تلريبية بصفة دورية ولتكن كل ثلاثة أثهر مثلا تعرف الطلاب بأهمية

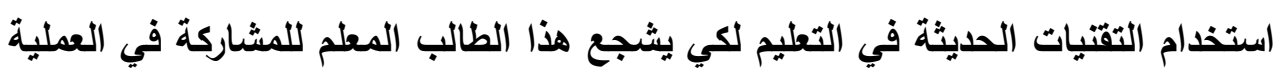

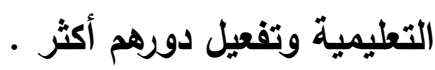

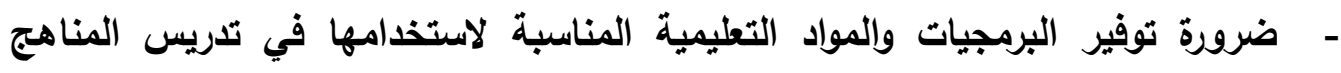
التعليمية بالمدراس اثناء فترة التدريب الميدانى خاصة والثناء اتلاريس بعد التخرج عامة . 


\section{المراجع}

اولاً : المراجع العربية : المابية

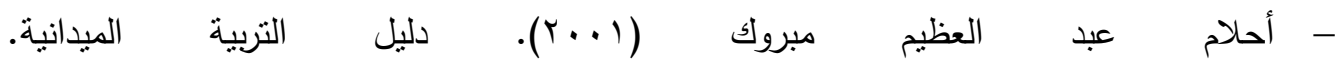

فttps://faculty.mu.edu.sa/aabdelazim:فى

- أحمد خيري كاظم، جابر عبد الحميد (9191 (). وسائل التعليمية والمنهج،القاهرة، دار النهضة.

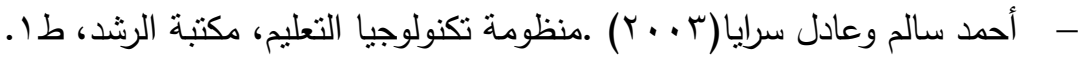

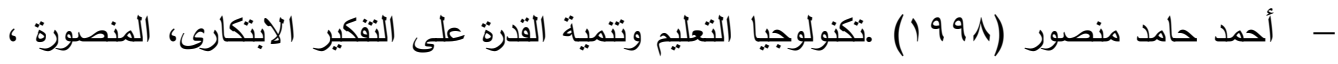
دار الوفاء للطباعة والنشر والتنوزيع لعن

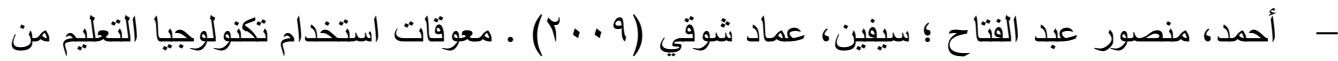
وجهة نظر معلمي الرياضيات في ضوء بعض المتغيرات. الجمعية المصرية لتربويات الرياضيات ،

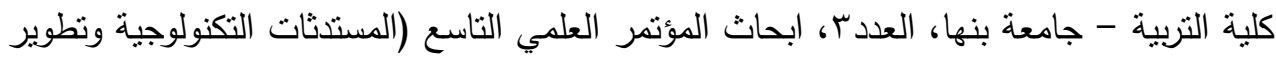
تدريس الرياضيات)، دار الضيافة - جامعة عين شمس ع - بأغسطس.

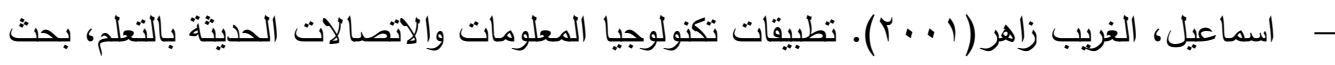
مقدم الى المؤتمر العلمي التاسع: للتربية وتتمية ثقافة المشاركة وسلوكيا في الوطن العربي، كلية

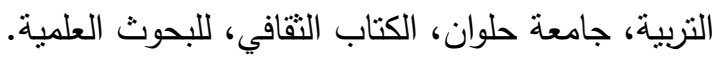

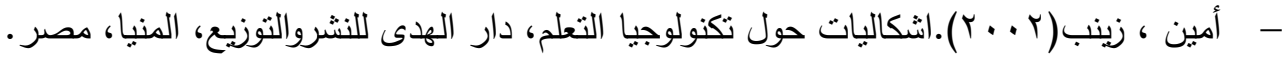

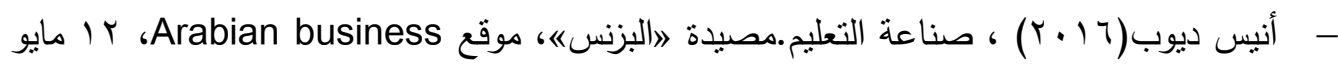

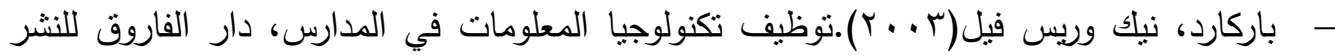

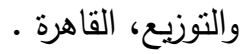
- بحري، منى يونس واخرون ( •991).التقنيات التربوية، دار الحكمة للطباعة والنشر، الموصل،

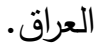
- - بدر عبداله الصالح ( 1991) .تطوير تقنية التعليم في المملكة العربية السعودية في ضوء

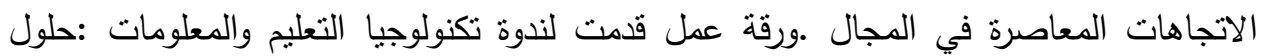
لمشكلات تعليمية ملحة .كلية التربية، جامعة الملك سعود، الرياض.

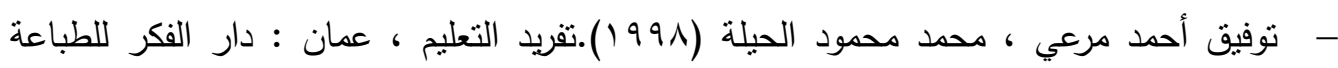

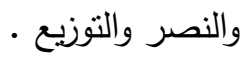




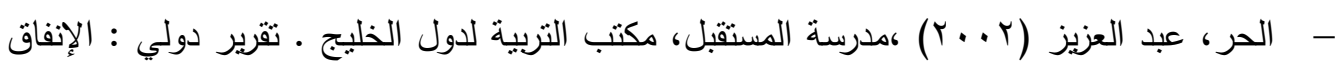

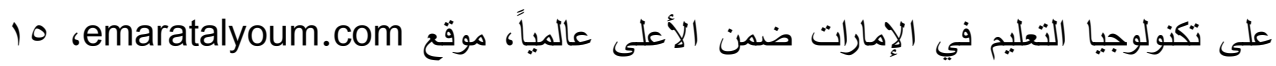
أغسطس.

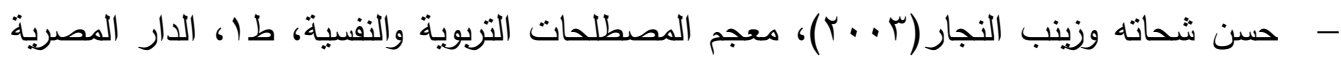
اللبنانية.

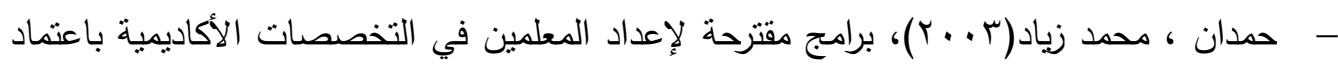

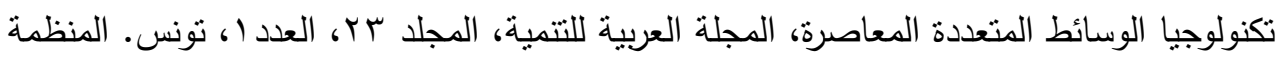

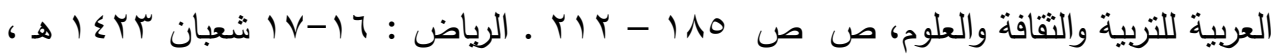
كلية التربية جامعة الملك سعود.

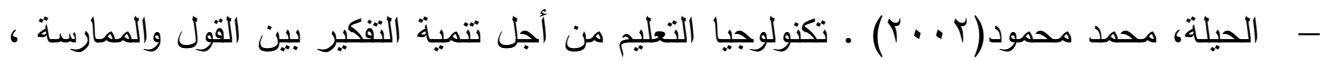
دار المسيرة للنشر والتوزيع والطباعة، عمان.

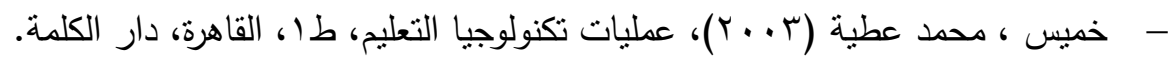

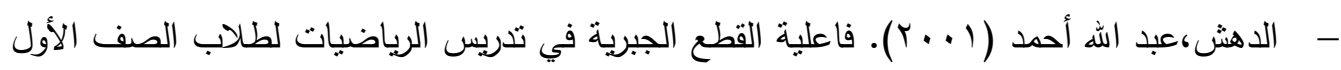

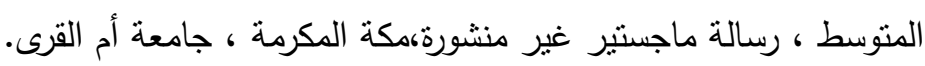

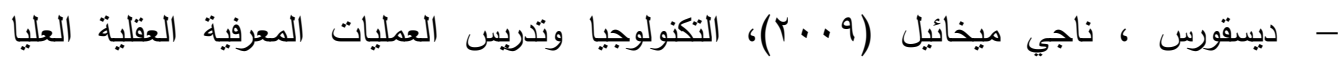
الرياضياتية "رؤى مستقبلية"، الجمعية المصرية لتربويات الرياضيات ، كلية التربية - جامعة بنها،

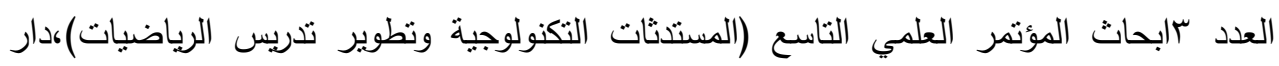

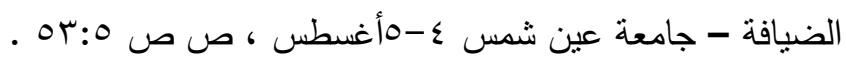

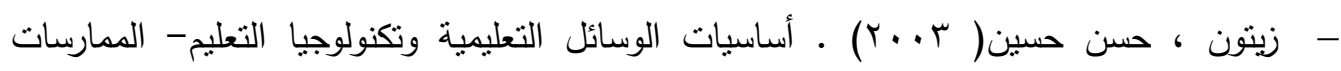

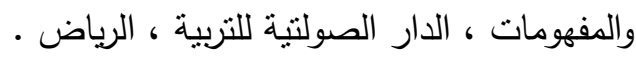
- - سبع محمد أبو لبدة (910 19) ، مبادئ القياس والتقويم التربوي، الجامعة الأردنية، عمان.

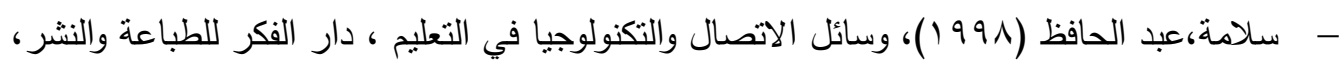
ط ط عمان

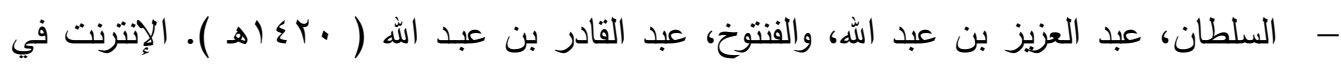

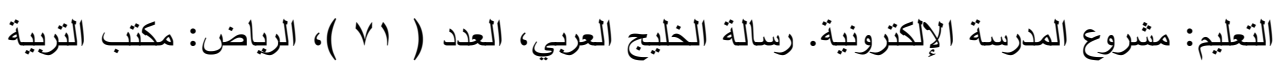

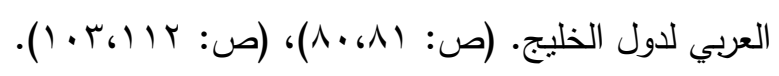

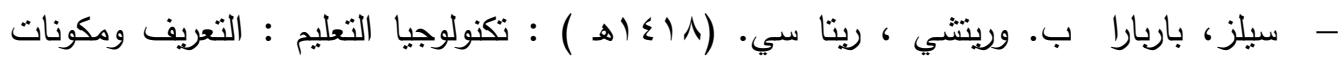

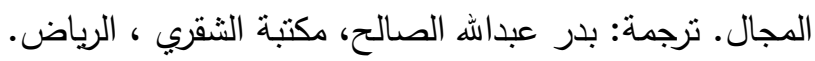


- - الصباغ،عبد المعطي محمد (ع (99)).مدى معرفة مدرسي كليات المجتمع في الأردن بالكفيايات

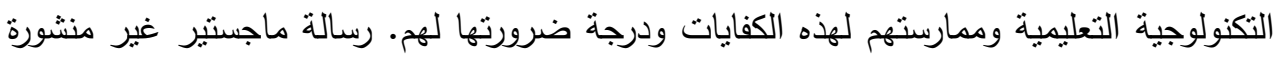

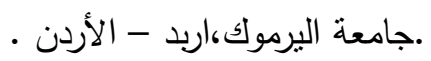

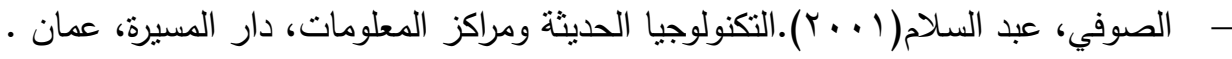

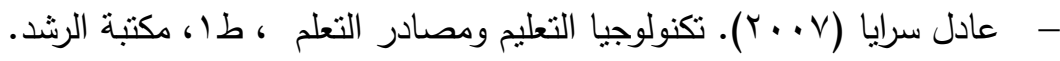

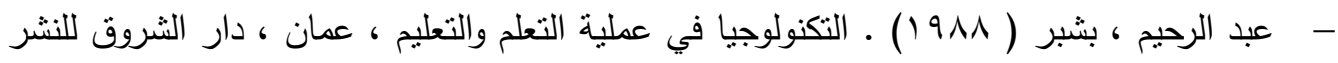

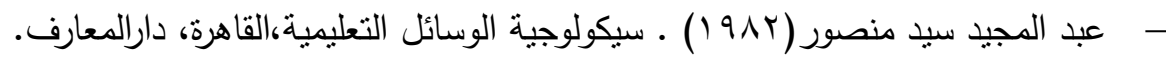

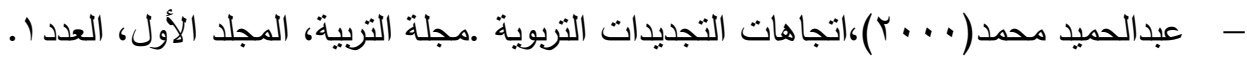

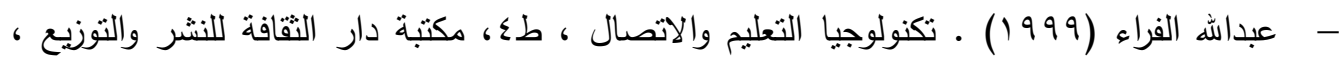
عمان - - العنزي ، بنت طاهر (Tس؟ (هـ ). فاعلية استخدام شبكات التواصل الاجتماعي في تحصيل العلوم والاتجاه نحو المعرفة لدى طالبات الصف الثالث المتوسط في المدينة المنورة ، منطلب تكميلي

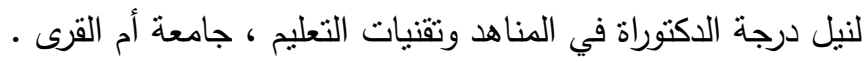

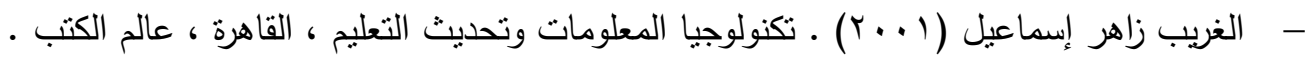

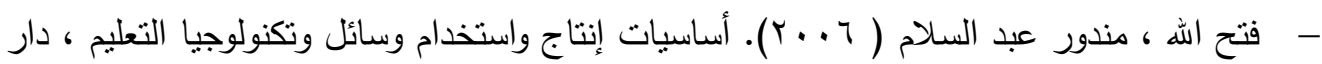
الصميعي للنشر والتوزيع ، الرياض.

- - فؤاد أبو حطب وسيد أحمد عثمان( 9 (197) ـ التقويم النفسي، مكتبة الانجلو المصرية، القاهرة.

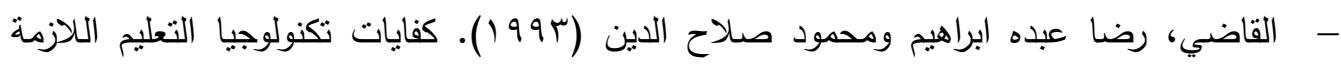

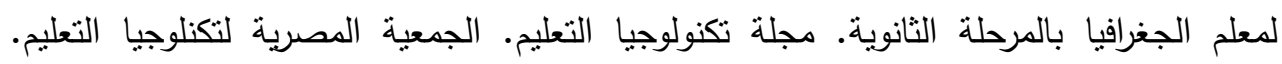
القاهرة ل - - الكلوب، بشير عبد الرحيم (1991) ـ التكنولوجيا في عملية التعليم والتعلم، دار الثروق للنشر والتوزيع،عمان.

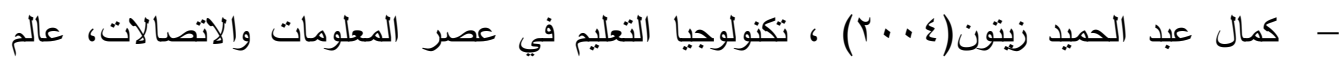
الكتب، القاهرة، طץ. - كمال يوسف إسكندر ، مجد الغزاوي (£991) ـ مقدمة في تكنولوجيا التعليم ، الكويت ، مكتبة • (الفلاح 


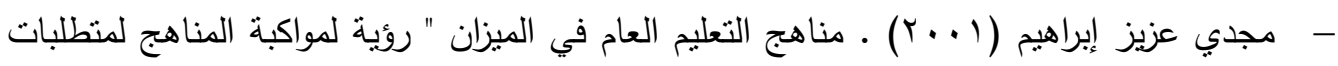

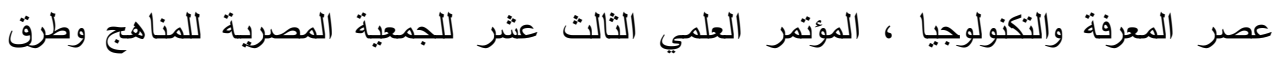

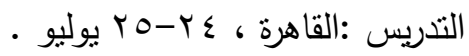
- محمد زياد حمدان(ع •ـأهـ) • التعلم الصفي تحفيزه وإدارته وقياسه، طا، المملكة العربية

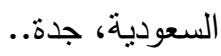

- - محمد زياد حمدان( • - (1) ). تقييم التعليم، دار العلم للملايين، بيروت.

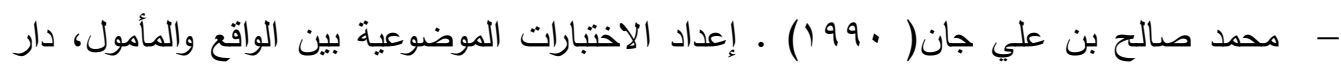

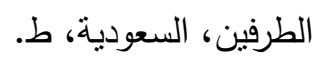

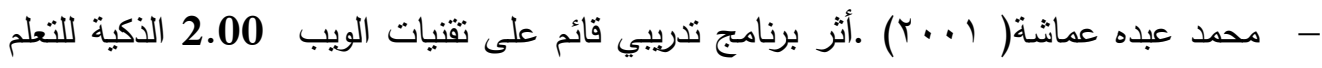

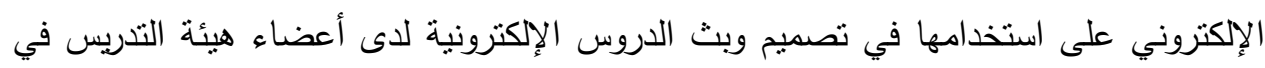

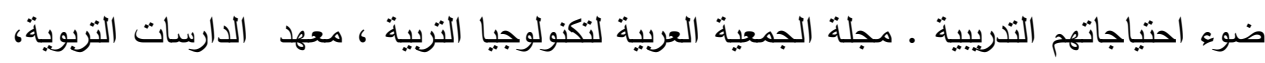
جامعه القاهرة. - - محمود أحمد محمود نصر (999 199) .أثر التعلم بالاكتشاف الموجه مصحوباً بالوسائل التعليمية

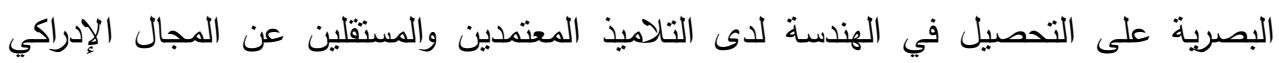

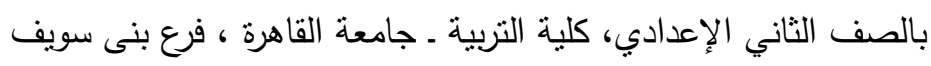

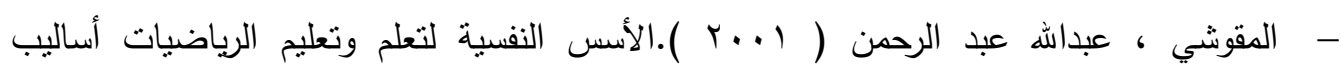

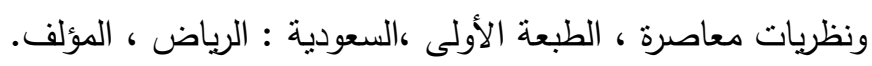

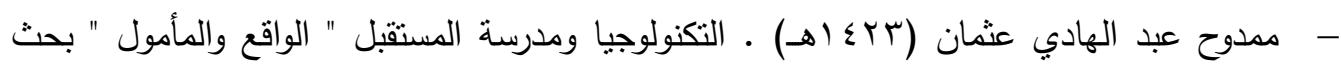

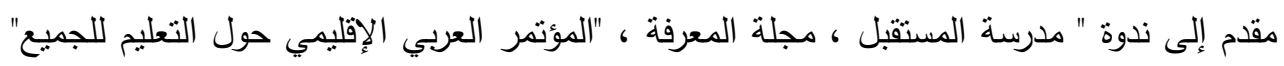

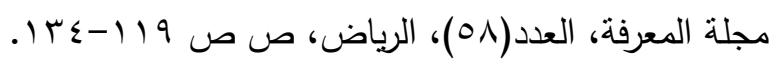

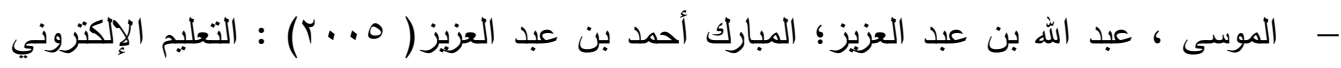
الأسس و التطبيقات ، الرياض : مكتبة العبيكان.

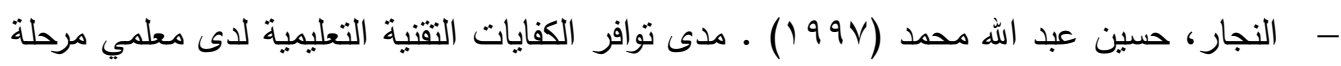

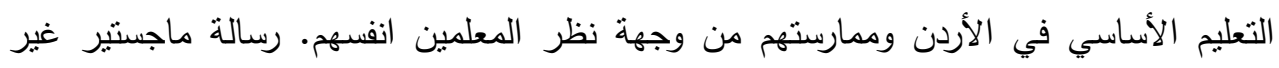

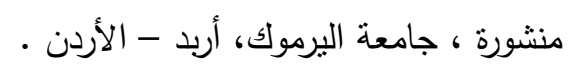

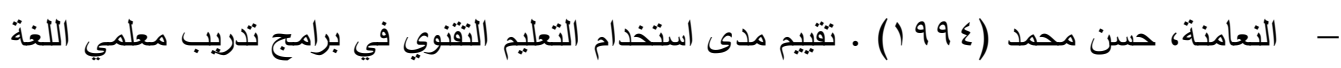
الانجليزية على المناهج (بترا) وأثز هذا الاستخدام على كفاياتهم التعليمية ـ رسالة ماجستير غير فئري

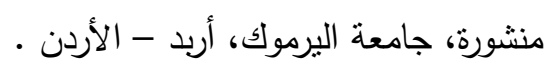


- - النعيمي، نجاح محمد (.99 19) • تتمية كفايات الطلاب المعلمين ف يمجال تكنولوجيا التعليم بكلية التزبية، جامعة قطر ، رسالة دكتوراة غير منشورة . جامعة عين شمس، القاهرة .

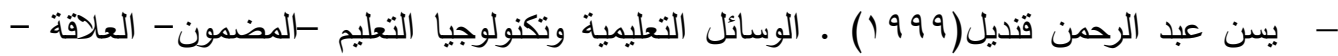

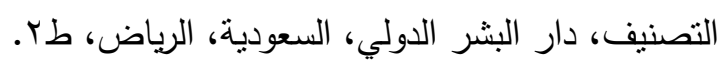

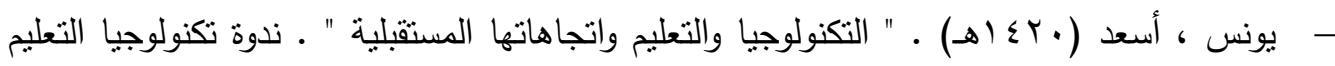
والمعلومات جامعة الملك سعود. كلية التربية.

ثانياً : المراجع الإجنبية : معلية

- Bitter , G, G (1985) : “ Survey Of Arizona Public School Practices And Needs For Computer Assisted Instruction " College Of education , Arizona State University, Journal Amouncement ; Dec ,1985

- Carol Fagan and Dan Lunley(1985): Planning for Tech Prep A Guide Book for School Leaders . N.Y: Scholastic Inc., 1995, PP. 8-9 .

- Claussen, J.(1992)." Functional Competencies of Technology Teachers Perceived to be Necessary by selected Teachers educators .Teachers Supervisor Directors, and public School Technology teachers " Dissertation Abstract International " 52(8) p.2895A.

- Clay,M.(1994):Technology Competencies of bignners Teacher Preparation Programs " Dissertation Abstract International".55(5)P.1244-A.

- Ely,P.(1992):" Trends in educational technology " (ERIC Document Reproduction service no. ED346850).

- Molenda, Michael, Russell, James D., \& Smaldino, Sharaon ( 1998) : Trends in Media and Tecnology in Education and Training. Educational Media and Technology Yearbook, vol.23. p. 2-15, Englewood, Co. Libraries Unlimited.

- Ramesh, N.I. (2011): Use of Technology to enhance teaching and learning in Mathematics and Statistics, MSOR Connections Vol 11 No 1 Spring Term.

- William.A.Mehrens \&Irivn(1978). Lehmann,Standardized Tests in Education, Rinehart and Winston, New York.

- Yalin, H(1993) A Study of Secondary school teachers competencies Necessary for the use of educational technology. 